\title{
Isotopic Assessment of Groundwater Salinity: A Case Study of the Southwest (SW) Region of Punjab, India
}

\author{
Gopal Krishan ${ }^{1}$ D , Mavidanam Someshwar Rao ${ }^{1}$, Rajesh Vashisht ${ }^{2}$, Anju Chaudhary ${ }^{1}$, Jaswant Singh ${ }^{3}$ \\ and Amit Kumar 4,*(D)
}

check for updates

Citation: Krishan, G.; Rao, M.S.; Vashisht, R.; Chaudhary, A.; Singh, J.; Kumar, A. Isotopic Assessment of Groundwater Salinity: A Case Study of the Southwest (SW) Region of Punjab, India. Water 2022, 14, 133. https://doi.org/10.3390/w14010133

Academic Editors: Jinguo Wang,

Zhi Dou, Hu Zheng and

Chao Zhuang

Received: 4 December 2021

Accepted: 30 December 2021

Published: 5 January 2022

Publisher's Note: MDPI stays neutral with regard to jurisdictional claims in published maps and institutional affiliations.

Copyright: (C) 2022 by the authors. Licensee MDPI, Basel, Switzerland. This article is an open access article distributed under the terms and conditions of the Creative Commons Attribution (CC BY) license (https:// creativecommons.org/licenses/by/ $4.0 /)$.
1 National Institute of Hydrology, Roorkee 247667, India; drgopal.krishan.nihr@gov.in (G.K.); 65somesh@gmail.com (M.S.R.); anju.nih@gmail.com (A.C.)

2 Department of Soil and Water Conservation, Chandigarh 160017, India; rvashisht_chd@yahoo.com

3 Department of Agriculture and Farmers' Welfare, SAS Nagar, Sangrur 160055, India; jaswantsingh731@gmail.com

4 School of Hydrology and Water Resources, Nanjing University of Information Science and Technology, Nanjing 210044, China

* Correspondence: amitkdah@nuist.edu.cn
Abstract: In recent decades, due to rapid increases in water demand and greater usage of water for irrigation from surface canals, waterlogging problems have been created in the southwest zone of Punjab, coupled with a stagnation in saline zone formation due to salinity ingression. To understand these salinity issues, the present study has been conducted in three districts (Muktsar, Fazilka, and Faridkot) of Punjab to understand the root cause. To this end, groundwater samples were collected from 142 piezometers developed at 40 sites. Electrical conductivity (EC) observations were taken in the field, and collected samples were analyzed for isotopes in the laboratory. Results found that salinity in groundwater arises from the combination of evaporation enrichment and salt dissolution. The dissolved salts may be acquired due to salts from aquifer materials or salts from surface soils dissolving and leaching down with the recharging water. Besides, the zone of interaction is mapped using stable isotopic composition. The study suggests that zone of interaction between aquifers can be effectively used in groundwater augmentation, management, and contamination control at regional and/or global scales to curb water demand in the future.

Keywords: salinity; isotopes; electrical conductivity; southwest Punjab; groundwater

\section{Introduction}

Generally, groundwater is used for irrigation in arid and semi-arid regions of the India and fulfills the demands of the huge population, but in the southwest (SW) region of Punjab, surface water is used for irrigation thanks to well-developed canal networks. Bonsor et al. [1] stated that the Punjab state of India, having great hydrogeological characteristics, underlies Haryana, Rajasthan, Delhi, and Punjab, where groundwater depletes at a rate of $109 \mathrm{~km}^{3}$ /year [2]. Further, it is a widely recognized state for groundwater utilization in India and is listed second in over-stressed aquifers globally [3]. In other parts of Punjab, such as the Indo-Gangetic basin, people rely heavily on groundwater, resulting in a rapid decline in the water demand, consequently impacting the quantity and quality of the water [1,4]. Groundwater salinity is also one of the quality issues [5] that has emerged in this region as a result of various factors [6,7]. Various approaches along with environmental isotopes have been found useful in finding the groundwater salinity's causes and mechanisms [8-11]. Multi-aquifer systems developed due to diverse geological formations, as well as the levels of salinity in these aquifers, may vary due to geogenic as well as anthropogenic reasons [12]. In general, the salinity of the groundwater could be increasing due to adequate availability of nitrate, fluoride, iron, total hardness, arsenic, and some toxic metal ions (e.g., $\mathrm{Cd}, \mathrm{Ni}, \mathrm{Pb}$ ) in several states of India, causing potential risks to human 
health [13-16]. In addition, if there is sufficient surface water availability, then inadequate use of groundwater leads to a rise in the groundwater level, resulting in waterlogging conditions that increase salinity $[6,17]$. In the SW region of Punjab, farmers copiously use canal water for irrigation, and in some parts, fluctuating groundwater levels have put water managers into a predicament in terms of separating the saline and freshwater zones.

In the modern era, stable isotopes $\left(\delta^{18} \mathrm{O}\right.$ and $\left.\delta \mathrm{D}\right)$ of water are widely used in hydrological studies for the identification of key sources of pollution and in other hydrological processes [18-22]. Besides, researchers of different works of life reported the application of environmental isotopes to identify the source of groundwater recharge and estimations of quality, quantity, dating, and their interconnections; seepage from tunnels, reservoirs, canals, etc.; contributions of snow-ice melt in glacier discharges; and nutrients, dynamics, and sedimentation in freshwater bodies (e.g., lakes, reservoirs) [23-26]. The relationship between $\delta^{18} \mathrm{O}$ and $\delta \mathrm{D}$ in freshwaters, i.e., $\delta \mathrm{D}=8 \times \delta^{18} \mathrm{O}+10$ [27], and their function is called "d-excess" and is represented by d-excess $=\delta \mathrm{D}-8 \times \delta^{18} \mathrm{O}$. The value of $\mathrm{d}$-excess varies due to evaporation at various stages [28]. The use of stable isotopes can be extremely useful in identifying various hydrological processes [6,29]; mechanisms [11]; sources [21,30]; characteristics of surface-groundwater interactions [22]; and depth-wise salinity variations [19] in India. In view of the above, the present study is carried out to (i) assess the present-day waterlogging and groundwater saline in aquifers at different depths in the southwest (SW) parts of Punjab and (ii) identify depth-wise saline water and freshwater zones in the aquifers using isotopes.

\section{Materials and Methods}

\subsection{Study Area}

The study was carried out in three districts, namely Fazilka, Muktsar, and Faridkot (Figure 1) of the SW region (Malwa) of Punjab, India, constituting a total land area of about $6932 \mathrm{~km}^{2}$. The geographical location of the study area lies between latitudes $29^{\circ} 54^{\prime} 20^{\prime \prime} \mathrm{N}$ and $30^{\circ} 49^{\prime} 52^{\prime \prime} \mathrm{N}$ and longitudes $73^{\circ} 52^{\prime} 4^{\prime \prime} \mathrm{E}$ and $75^{\circ} 03^{\prime} 22^{\prime \prime} \mathrm{E}$. There are a total of 10 administrative blocks, with 4 distributed in the Fazilka district, 4 in the Muktsar district, and 2 in the Faridkot district. The study area shares an international boundary with Pakistan to the west and a state boundary with Rajasthan to the south, and within the state of Punjab, the Bhatinda district is to the east, and the districts of Firozpur and Moga are to the north. Physio-graphically, it is in the Sutlej sub-basin and is covered extensively by the Sutlej Canal network, including Indira Gandhi Canal and Ganga Canal (Bikaner Canal), two major canals of the state of Rajasthan.

\subsubsection{Demography}

As per the census 2011 [31], the study area, comprised of 3 districts, had a population of 2.7 million, with a share of $9.73 \%(10 \%)$ of Punjab state's population living within, and during 2001-2011, districts Faridkot, Fazilka, and Muktsar had population growth rates of $12.18 \%, 13.12 \%$, and $16.1 \%$; average population densities of 424,380 , and 348 persons per square kilometer $\left(\mathrm{km}^{2}\right)$, which are greater than the national average of 327 persons $/ \mathrm{km}^{2}$; sex ratios (female/male) of $889 / 1000,923 / 1000$, and 895/1000; and literacy rates of $70.6 \%$, $70.7 \%$, and $66.8 \%$, respectively.

\subsubsection{Hydrogeology and Climate}

In this study, very high spatial resolution daily gridded rainfall data $(0.25 \times 0.25$ degree $)$ have been taken from the Indian Metrological Department (IMD, Pune) for the period of 1901 to 2019 and plotted in Figure 2. The normal annual rainfall is $449 \mathrm{~mm}$, and 80\% of it occurs during the SW monsoon season. The study area is a part of Sutlej Basin and developed by Indo-Gangetic alluvium, with alluvial plains occupying maximum area, followed by sand sheets and sand dunes as patches. Evidence shows that a paleochannel exists in the central part of the Faridkot district, and there are sequences of Quaternary deposits of Mid-Pleistocene to Recent age, comprising fluvial and arid phases in an alternate 
manner. The older alluvium originates from the Himalayas, and recent Aeolian deposits have been laid down by the action of wind from the Thar Desert of Rajasthan. The study area is underlain by a multi-aquifer system formed by intermittent layers of clay and a number of granular layers (Figure 3), which extends to a depth of up to $300 \mathrm{~m}$. The aquifers are composed of fine- to coarse-grained sand, further separated by a $25-40 \mathrm{~m}$ thick clay zone [32]. The first aquifer (composed of fine- to coarse-grained sand) is a water table aquifer and extends all over the area.

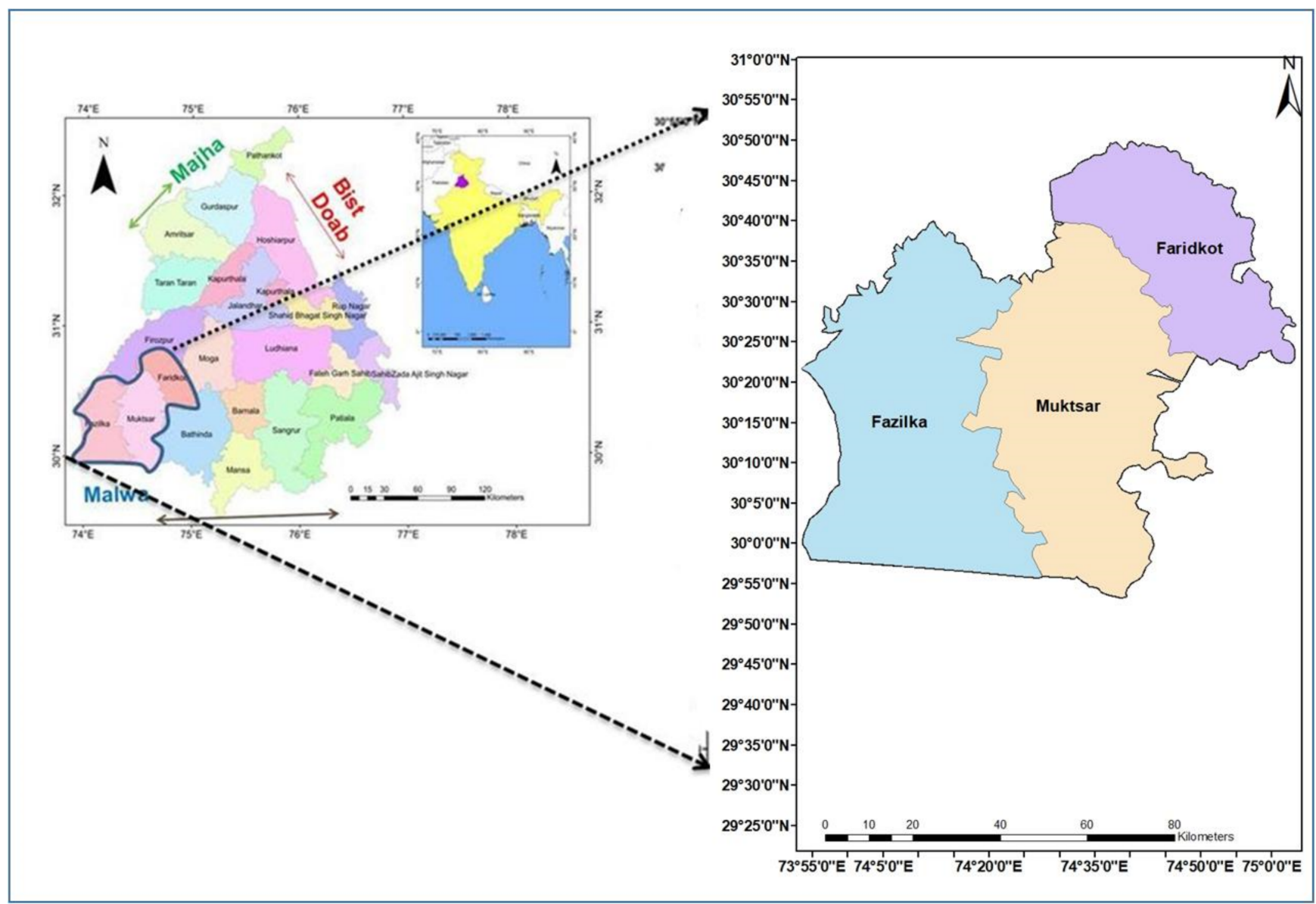

Figure 1. Study area map showing three districts in Punjab under study.

\subsubsection{Agriculture and Irrigation}

Agriculture is the major occupation in the study area, with two main cropping seasons of July to December (Kharif) (maize, bajra, paddy, cotton, mash, moong, arhar, moth, sugarcane, etc.) and December to April (Rabi) (barley, gram, wheat, taramera, sarson, toria, etc.) in a year. Major sources of irrigation are surface water and groundwater, but due to the issues of groundwater salinity, canal water is largely used to fulfill irrigation needs.

\subsection{Methodologies Adopted}

For separating out the zone of freshwater and saline water horizontally as well as vertically, the Department of Agriculture \& Farmers' Welfare (DAFW), Punjab has constructed a network of depth-specific piezometers at 40 sites in consultation with the National Institute of Hydrology (NIH), Roorkee in the study area (Figure 4). 


\section{Fazilka}

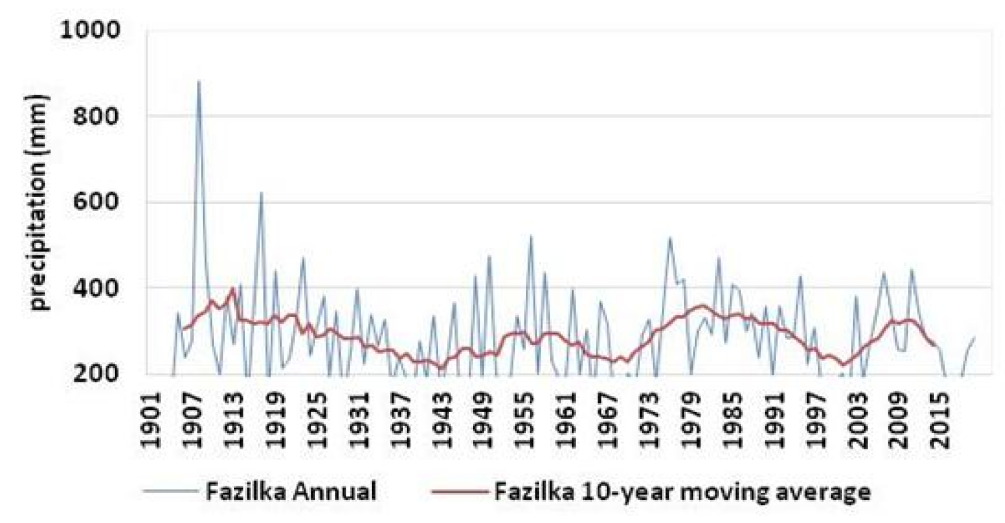

\section{Faridkot}

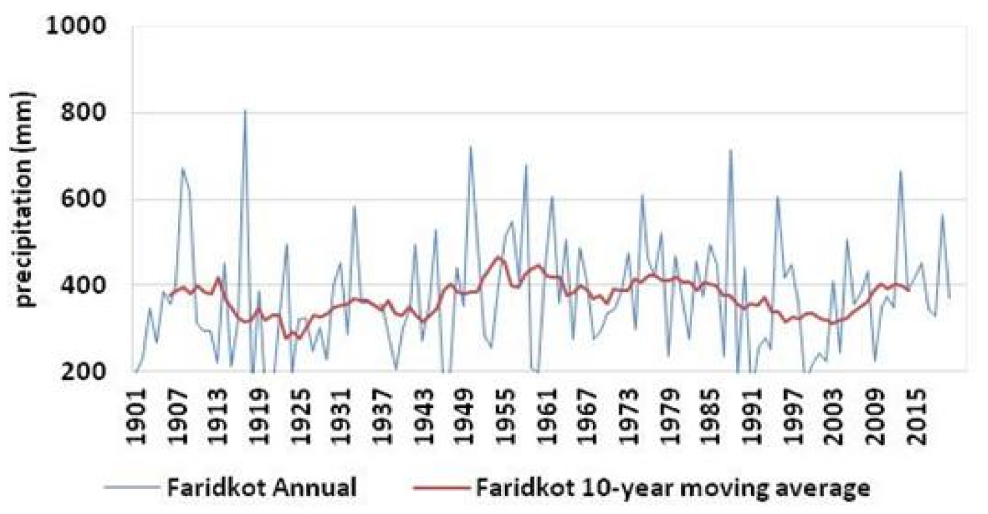

Muktsar

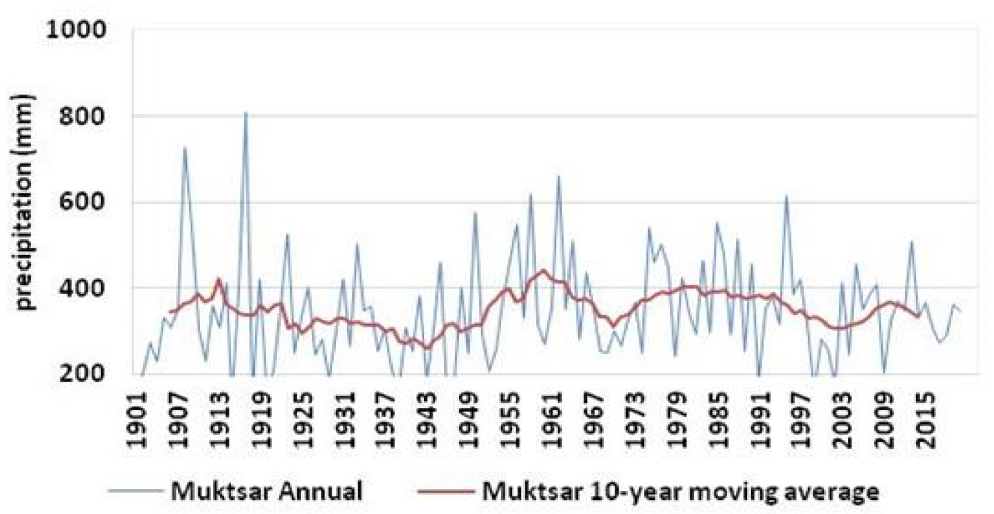

Figure 2. Rainfall variation during the period of 1900-2019 in Fazilka, Muktsar, and Faridkot.

\subsubsection{Piezometer Construction}

Depth-specific piezometer construction was carried out at sites shown in Figure 4 using the standard methodology. The site selection for the installation of clusters of piezometers was done by DAFW, Punjab. Based on the evaluation of available geological information, the locations of boreholes and the collection zones were carefully selected in constructing the piezometers. In this study, $250 \mathrm{~mm}$ (10 in) drilling was done below the proposed location of the piezometer, the top and bottom parts were filled with clean, fine sand, and bentonite was used for sealing. 

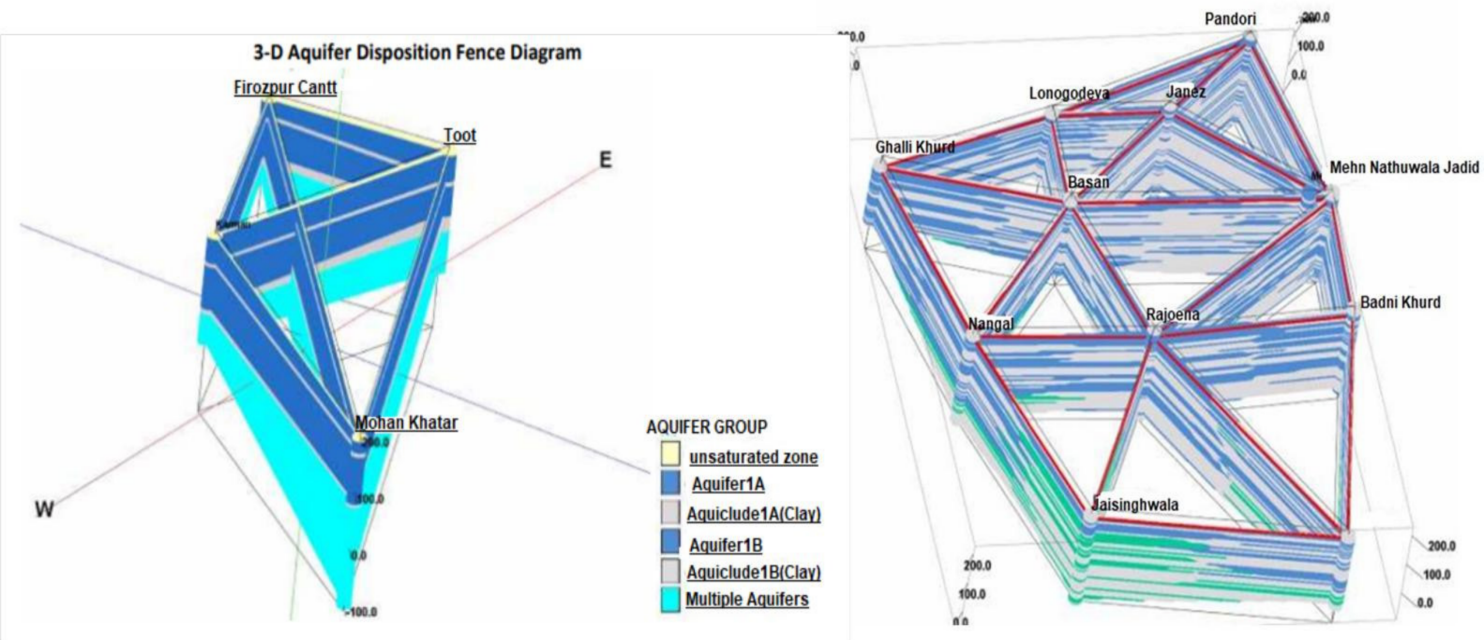

Figure 3. Lithology of the study area [33].

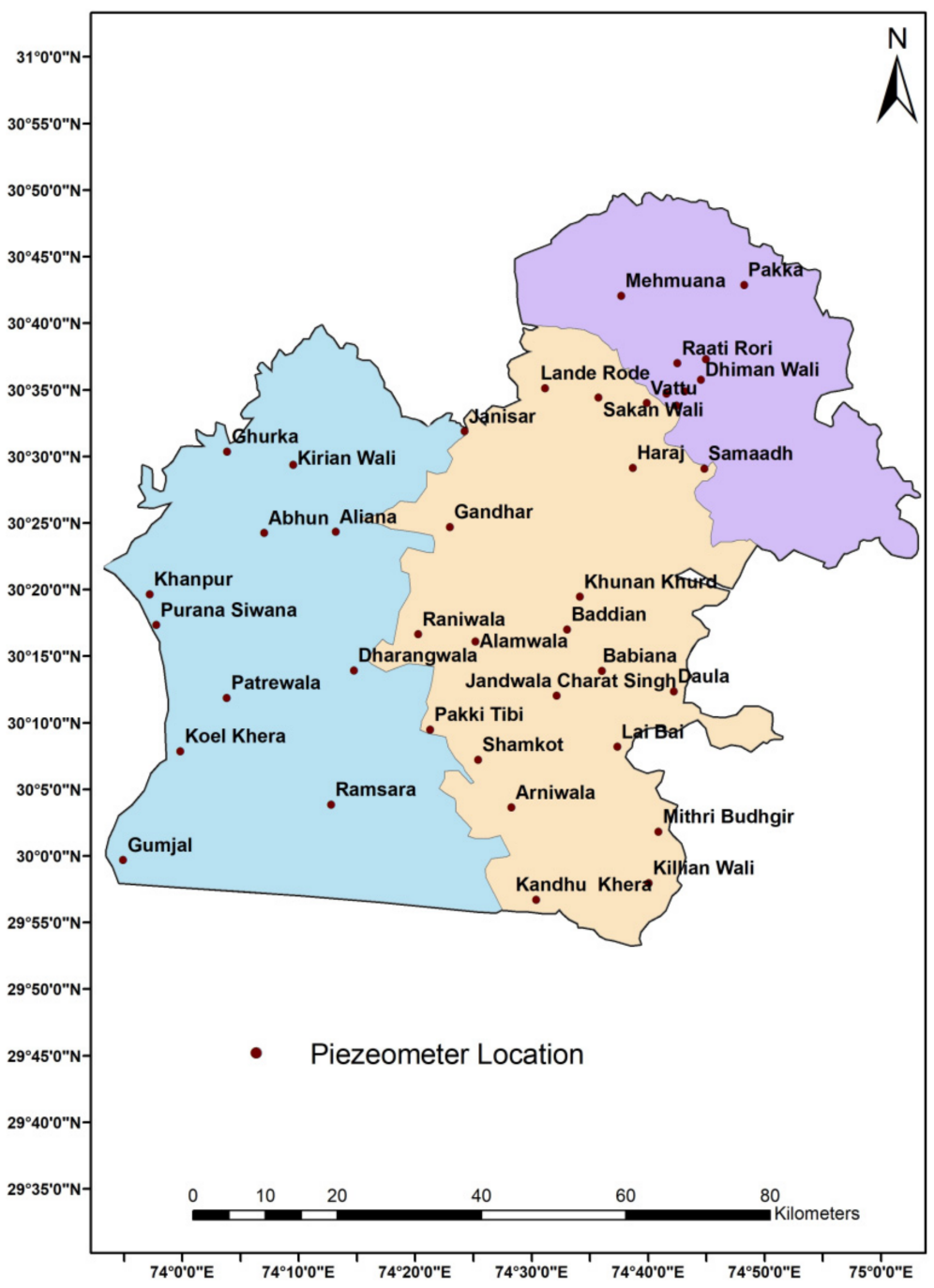

Figure 4. Piezometer development sites in the study area (Fazilka, Muktsar, and Faridkot).

\subsubsection{Sampling and Analysis}

Groundwater samples were collected in three campaigns from the newly drilled depthspecific piezometers during November-December 2019 (6 sites); February 2021 (16 sites); 
and August 2021 (18 sites). To avoid errors, samples were carefully collected in triplicate in fresh, clean, and dry LDPE (low-density polyethylene) Tarson bottles for the laboratory analysis of stable isotopes $\left(\delta^{18} \mathrm{O}\right.$ and $\left.\delta \mathrm{D}\right)$. Collected samples were transported in ice boxes and preserved at $4{ }^{\circ} \mathrm{C}$ before analysis [34,35]. Prior to sampling, on-site analyses of $\mathrm{pH}$ and electrical conductivity (EC) were done using portable instruments ( $\mathrm{pH}$ meter and Eutech portable EC, respectively).

The stable isotopic ratios $\left(\delta^{18} \mathrm{O}\right.$ and $\left.\delta \mathrm{D}\right)$ were measured by dual-inlet isotope ratio mass spectrometer (DI-IRMS) (Isoprime GV instruments, Cheadle, UK) with a precision of $\pm 0.1 \%$ for $\delta^{18} \mathrm{O}$ and $\pm 1.0 \%$ for $\delta \mathrm{D}$. In dual-inlet IRMS, the inlet is alternately switched for analysis between standard and reference gas by adjusting their volumes with the help of changeover valve to obtain matching pressure, which helps in improving accuracy. For deuterium analysis and oxygen analysis, hydrogen gas in the presence of a platinum catalyst and $\mathrm{CO}_{2}$ are equilibrated at $40{ }^{\circ} \mathrm{C}$ for $7 \mathrm{~h}$ and $2.5 \mathrm{~h}$, respectively, and then filled into the sample bellow after being dehydrated by passing through a cold finger. Reference gas is pre-filled into the reference bellow, and equal volumes of sample gas and reference gas are alternately purged into the mass spectrometer for isotopic analysis.

All spatially varying databases were analyzed by the ARC/GIS tool (version 10.1). In the present study, groundwater samples were collected from 142 newly developed piezometers by the Department of Agriculture \& Farmers' Welfare, Punjab at 40 sites, and the respective isotopic values $\left(\delta \mathrm{D}\right.$ and $\left.\delta^{18} \mathrm{O}\right)$ were measured.

Measurement and Analysis of Groundwater Salinity

Groundwater salinity is generally of 3 types [6]: (i) natural/primary salinity; (ii) dryland/secondary salinity; and (iii) tertiary/irrigated salinity. Based on the origin of salinity, it may be classified as [36] (i) marine origin; (ii) terrestrial origin—natural, due to processes of evaporation, dissolution, etc.; (iii) terrestrial origin-anthropogenic reasons; or (iv) mixed origin. Electrical conductivity $(\mathrm{EC}-\mu \mathrm{S} / \mathrm{cm})$ of groundwater samples was measured and was also used to compute total dissolved solids (TDS in $\mathrm{mg} / \mathrm{L}$ ) by applying calculations as given below:

$$
\begin{gathered}
\mathrm{TDS}=\mathrm{EC} \times 0.64 \mathrm{EC} \text { ranges from } 100 \text { to } 5000 \mu \mathrm{S} / \mathrm{cm} \\
\mathrm{TDS}=\mathrm{EC} \times 0.64 \text { when } \mathrm{EC}>5000 \mu \mathrm{S} / \mathrm{cm}
\end{gathered}
$$

Water is defined to be freshwater at salt concentration $<1000 \mathrm{mg} / \mathrm{L}$, potable for drinking at $<500 \mathrm{mg} / \mathrm{L}$ for palatability. The permissible limit of salinity for drinking water is $2000 \mathrm{mg} / \mathrm{L}$, and beyond that, it is considered saline [37].

\section{Measurements of Stable Isotopes}

Measurements of stable isotopes are done in terms of abundance ratios, i.e., atomic mass of heavy atom to the atomic mass of light atom. Only the relative difference in the ratio of the heavy isotopes to the more abundant light isotope of the sample, with respect to a reference, is determined. The difference is designated by a Greek letter $\delta$ and is defined as follows:

$$
\delta=\left(R_{\text {sample }}-R_{\text {reference }}\right) / R_{\text {reference }}
$$

where Rs denote the ratios of ${ }^{18} \mathrm{O} /{ }^{16} \mathrm{O}$ and $\mathrm{D} / \mathrm{H}$ isotopes in the case of water.

The difference between samples and references is usually quite small, and $\delta$ values are therefore expressed in per mille differences (\%o), i.e., per thousand.

$$
\begin{gathered}
\delta(\% \text { o })=\delta \times 1000 \\
\delta(\% \text { o })=\left[\left(\mathrm{R}_{\mathrm{s}}-\mathrm{R}_{\mathrm{r}}\right) / \mathrm{R}_{\mathrm{r}}\right] \times 10^{3}=\left[\left(\mathrm{R}_{\mathrm{s}} / \mathrm{R}_{\mathrm{r}}\right)-1\right] \times 10^{3}
\end{gathered}
$$

If the $\delta$ value is positive, it refers to the enrichment of the sample in the heavy isotope species, with respect to the reference, and the negative value corresponds to the sample depleted in the heavy isotope species. 
The relation between $\delta \mathrm{D}$ and $\delta^{18} \mathrm{O}$ can be written in a standard form (equation for straight line):

$$
\delta \mathrm{D} \%=\mathrm{A} \delta^{18} \mathrm{O}+\mathrm{d}
$$

where $A$ is the slope and $d$ is the intercept of the $\delta \mathrm{D}-\delta^{18} \mathrm{O}$ line of fresh global meteoric waters.

Regional and local meteoric water lines were developed in the pattern of a standard relationship between $\delta \mathrm{D}$ and $\delta^{18} \mathrm{O}$.

$$
\begin{aligned}
& \text { For northern hemisphere: } \delta \mathrm{D}=8 \delta^{18} \mathrm{O}+10 \\
& \text { For southern hemisphere: } \delta \mathrm{D}=8 \delta^{18} \mathrm{O}+22
\end{aligned}
$$

New relationship (1993) for northern hemisphere: $\delta \mathrm{D}=8.17 \delta^{18} \mathrm{O}+11.27$

\section{Results and Discussion}

In order to fulfill the desired objectives, in addition to the isotope analysis of the samples, the land features were mapped and analyzed. Important land features of the study area are shown in Figure $5 \mathrm{a}-\mathrm{d}$.

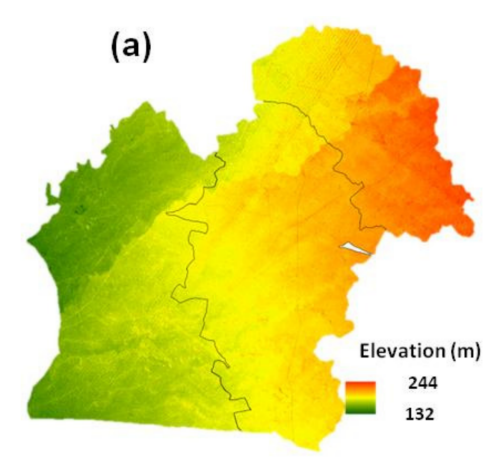

(c)

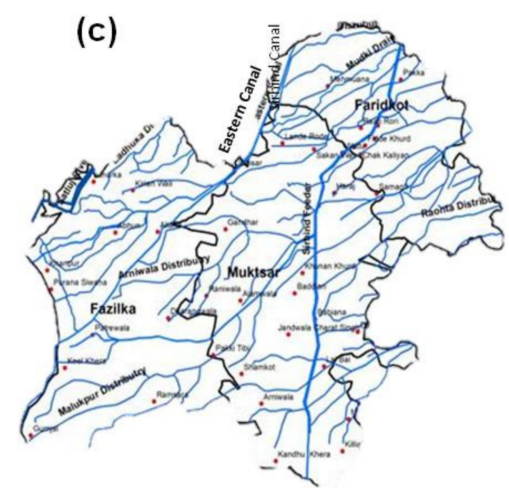

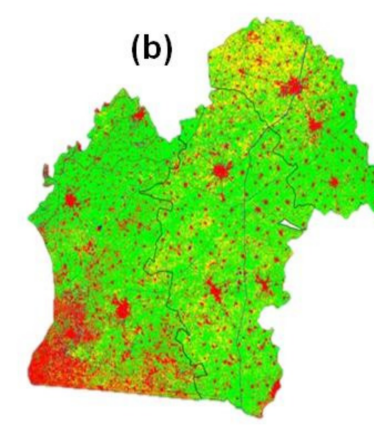

\begin{tabular}{|l|l|l|}
\hline Legend & LULC & $\begin{array}{l}\text { Area }\left(\mathbf{k m}^{2}\right) \\
(\%)\end{array}$ \\
\hline$\square$ & $\begin{array}{l}\text { Surface } \\
\text { water }\end{array}$ & $\begin{array}{l}245.99 \\
(3.55 \%)\end{array}$ \\
\hline$\square$ & Settlement & $\begin{array}{l}1139.56 \\
(16.44 \%)\end{array}$ \\
\hline$\square$ & Fellow land & $\begin{array}{l}1682.28 \\
(35.27 \%)\end{array}$ \\
\hline$\square$ & Agricultural & $\begin{array}{l}3863.21 \\
(55.73 \%)\end{array}$ \\
\hline
\end{tabular}

(d)

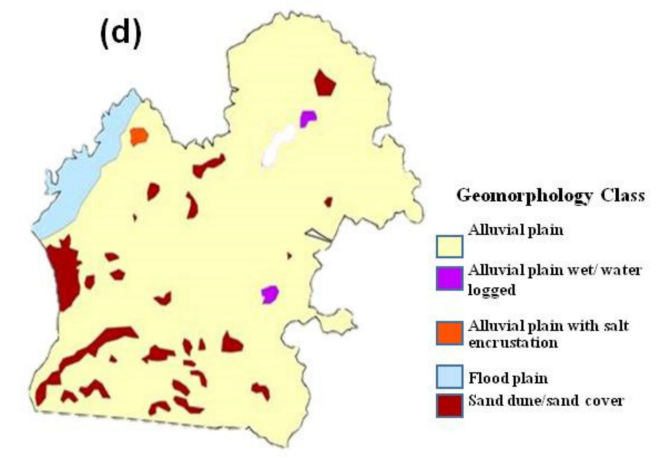

Figure 5. Important land surface features of the study area. Where (a) DEM of the study area (source: SRTM data); (b) LULC of Kharif season (source: SENTINEL-2, MSI data); (c) canal network: Eastern canal, Sirhind canal, and other minor canals in the study area; and (d) geomorphology.

\subsection{Surface Topography}

A digital elevation model (DEM) is prepared with $30 \mathrm{~m}$ resolution (1-arcsecond) SRTM data (Figure 5a) to map the elevation and slope features (shows elevation variation) in the range from $132 \mathrm{~m}$ to $244 \mathrm{~m}$, having a general topographic slope largely in the east-west direction. The ground elevation varies between $132 \mathrm{~m}$ above sea level ( $\mathrm{m}$ asl) and $244 \mathrm{~m}$ asl in the study zone.

\subsection{Land Use and Land Cover}

A land use and land cover (LULC) map has been prepared using the Sentinel 2 multispectral imaging mission, showing habitat settlements, agricultural land (56\%), fallow land 
( $24 \%)$, forest, and water bodies $(20 \%)$, as shown in Figure $5 \mathrm{~b}$. Results reveal that agriculture takes up a large share of the study area and requires high water demand, resulting in an increase in salinity.

\subsection{Geomorphology and Surface Soil Features}

A major part of the study area in the Sutlej Basin is occupied by alluvial plains. Further area is formed by the deposition of sediments with a low-lying flat topography. Some portions on the western side are flood plains, and some isolated patches of sand dunes are also found. Geomorphology of the study area is shown in Figure 5c. Soils are loamy, sandy desert soils and sodic and saline soils. The salt-affected soils identified in the study area are: soils with slight to moderate salinity and sodicity mostly on the surface; soils with slight salinity and sodicity throughout the soil profile; soils with moderate to high sodicity in the sub-soil; and soils with moderate salinity and strong sodicity on the surface and in the subsoil.

\subsection{Drainage}

The drainage system comprises a dense network of canals, as shown in Figure $5 \mathrm{~d}$. The water from these canals (Sirhind Feeder, Bikaner Canal, Rajasthan Feeder, Bathinda and Abohar branches of Sirhind Canal) is mainly used for irrigation purposes and has been fulfilling the irrigation demands of farmers for a long time. Similarly, there are large water bodies near the towns of Panjgrain, Khara, Jaito Mandi, Faridkot, and Wara Daraka that generally get dry in the summer.

\subsection{Groundwater Level Variations}

The temporal variation of groundwater levels monitored in the three districts of the study area in the years 2000 and 2014 was analyzed to infer the groundwater fluctuation. In the total study area, the groundwater level varied between 0.20 and $27.40 \mathrm{~m}-\mathrm{bgl}$ (168.45 to $220.45 \mathrm{~m}$ asl). It is inferred that there is a notable increase of $1-2 \mathrm{~m}$ in the groundwater levels in the Fazilka and Muktsar districts, while the groundwater levels decreased in the Faridkot district by an average of about $4 \mathrm{~m}$ (Figure 6). The variation in groundwater levels (2000 and 2014) shown for pre-monsoon and post-monsoon seasons are shown in Figures 7 and 8, respectively.

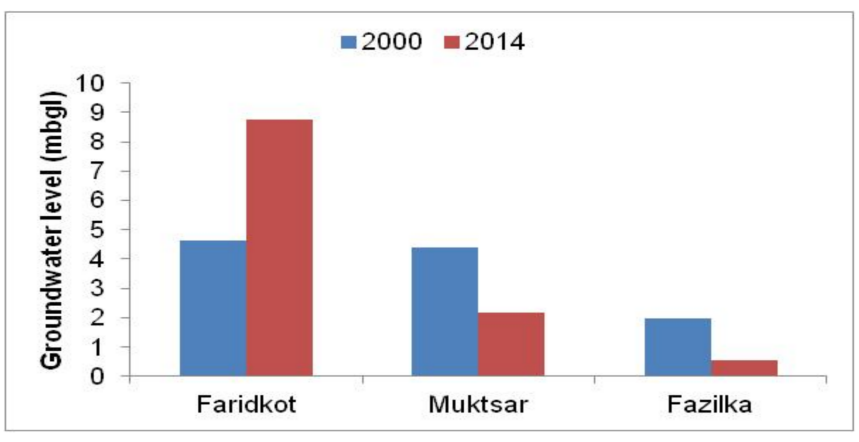

Figure 6. Water level variations (2000-2014) in Faridkot, Muktsar, and Fazilka.

\subsection{Spatial and Depth-Wise Salinity Variations}

In the present study, salinity has been measured for all 142 piezometers at different depths, and location details are given in Figure 4. Groundwater salinity variation with depth, as shown in Figure 9, indicates that higher salinities are observed at depths 5-10 m and $>20 \mathrm{~m}$. The majority $(>70 \%$ ) of the water samples have salinity $>1000 \mathrm{mg} / \mathrm{L}$, and out of these, $>32 \%$ of water samples have salinity greater than the drinking water permissible limit of $2000 \mathrm{mg} / \mathrm{L}$. However, as discussed earlier, these values vary with aquifer depth and location of the piezometer. 


\subsection{Isotope Database of Groundwater and Its Analysis}

Isotopes have been used effectively in hydrological studies for providing vital information in a wide range of studies related to soil moisture variation; its movement and recharge through unsaturated zones; origin, age, and distribution of waters in a region including an occurrence and recharge mechanism; inter-connections between groundwater bodies and identification of recharge sources and areas; and investigation of groundwater contamination, including salinization, etc. [38]. Variations in the values of stable isotopes of water $\left(\delta^{18} \mathrm{O}\right.$ and $\left.\delta \mathrm{D}\right)$ result from isotope fractionation occurring under equilibrium and non-equilibrium conditions during both physical and chemical processes. Condensation is predominantly an equilibrium process, whereas evaporation occurs under non-equilibrium conditions [39].
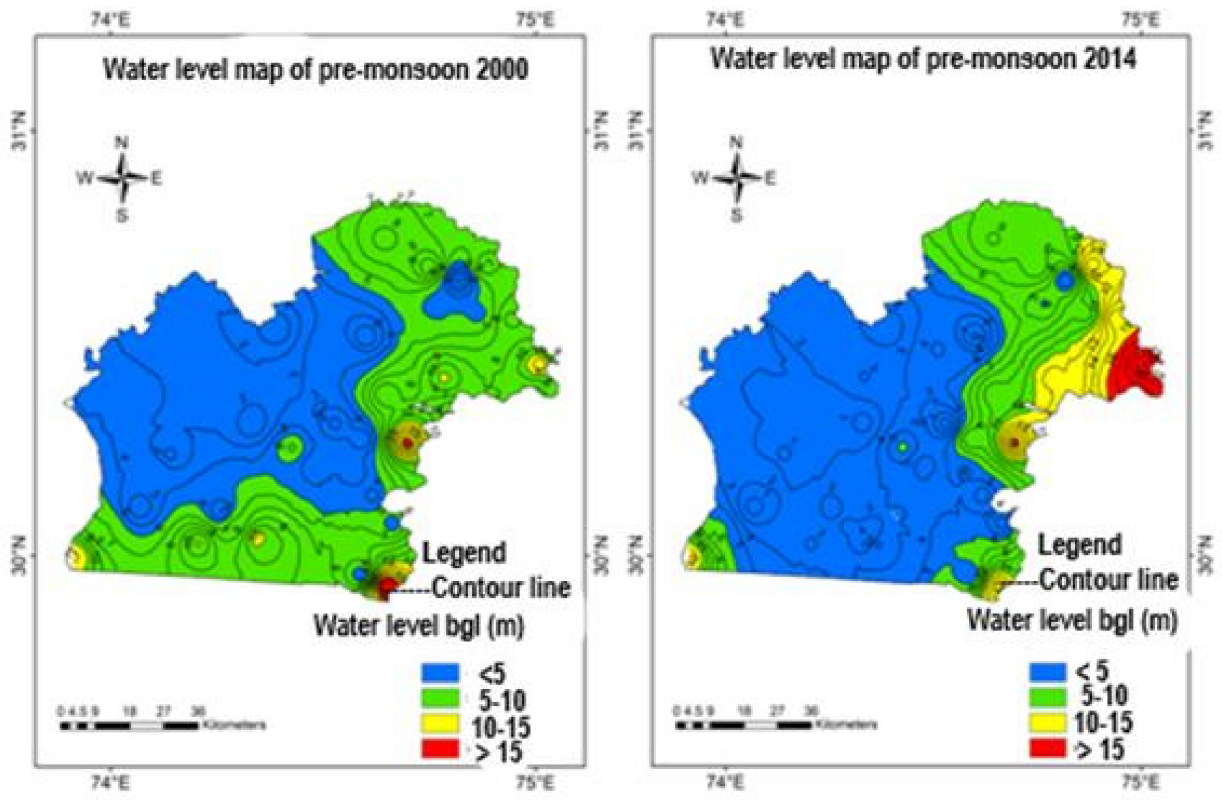

Figure 7. Water level map for pre-monsoon in Fazilka, Muktsar, and Faridkot.
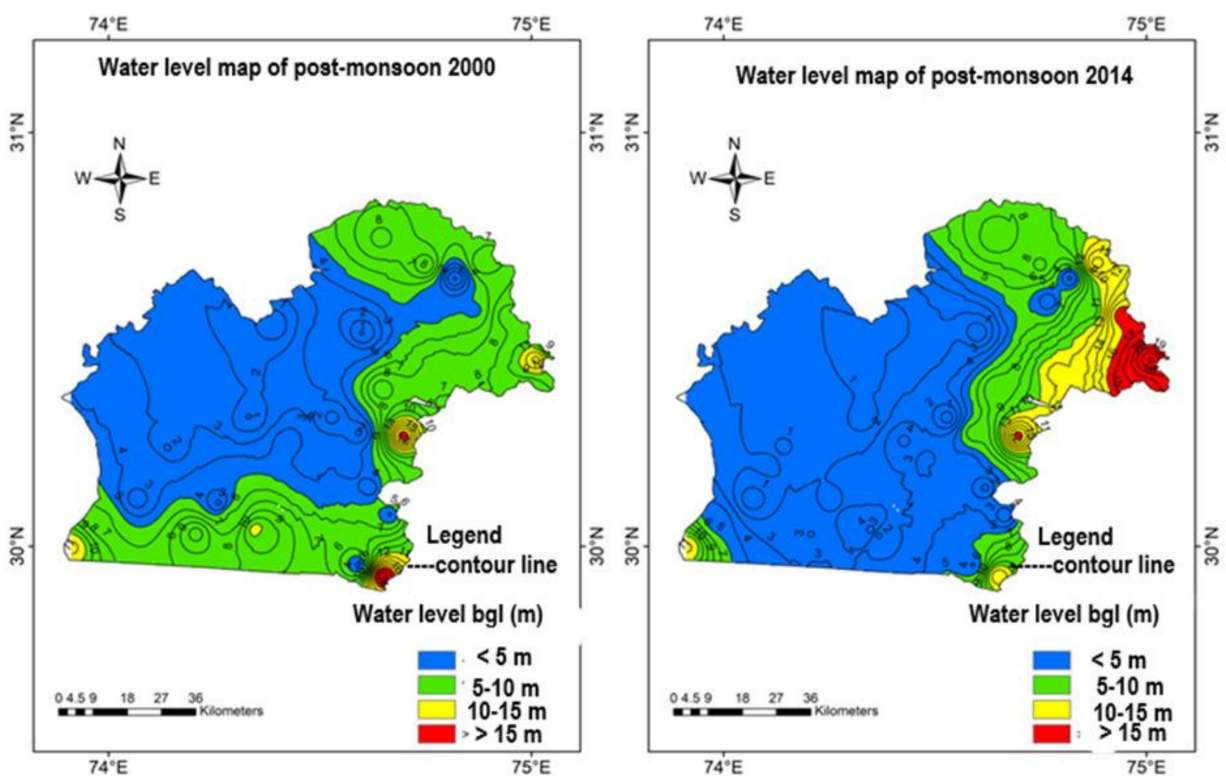

Figure 8. Water level map for post-monsoon in Fazilka, Muktsar, and Faridkot. 

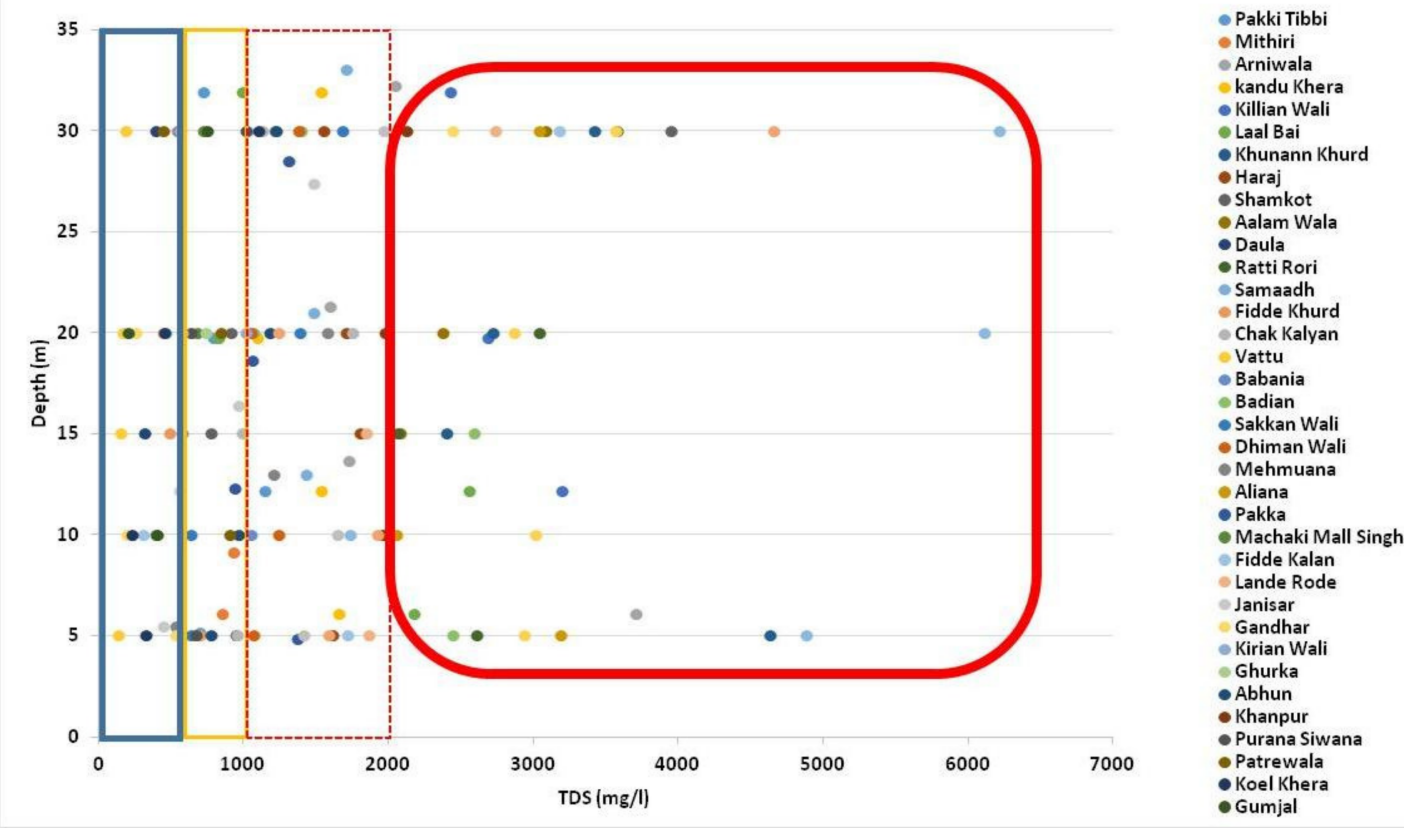

Figure 9. Depth-wise salinity variations in piezometers in the study area.

Variations in stable isotope characteristics of groundwater are generally found due to different sources of recharge and their relative proportions. Therefore, if there is any change in the stable isotope composition of groundwater, it will reflect the same in recharge conditions (recharge zone and recharging source) and vice versa. This technique can be effectively used in conditions where there are alternating layers of freshwater and saline water in aquifers $[6,11,19]$.

In the study, stable isotopes for identifying isotopic characteristics are employed in a cross plot between stable oxygen and hydrogen values, shown in Figure 10. The characteristic equations and the data range are given in Table 1, and for the study area, these are provided by Krishan et al., [21]. Stable isotope data given in Figure 10 and Table 1 show that groundwater lines (for different depths) falls below the river Sutlej/canal and rainfall isotopic lines, indicating possibilities of groundwater recharge from canals. For more detailed analysis, depth-wise spatial distribution maps of stable isotopes were plotted.

Table 1. Stable isotope composition of groundwater of districts Fazilka, Faridkot, and Muktsar.

\begin{tabular}{lll}
\hline Source & $\begin{array}{l}\text { Equation (Calculated from Monthly } \\
\text { Weighted Average) }\end{array}$ & Range ( $\left.\boldsymbol{\delta}^{\mathbf{1 8}} \mathbf{O} ; \delta \mathrm{D}\right)$ \\
\hline GMWL (Rozanski et al., 1993) & $\delta \mathrm{D}=8.17 \delta^{18} \mathrm{O}+10.35$ & - \\
Precipitation (Dolbaha) (Krishan et al., 2021) & $\delta \mathrm{D}=7.9 \delta^{18} \mathrm{O}+5.48 ; \mathrm{R}^{2}=0.96 ; n=322$ & $10.9,-15 ; 67.5,-117.3$ \\
$\begin{array}{l}\text { River Sutlej (Krishan et al., 2021) } \\
\text { Canal (Krishan et al., 2021) }\end{array}$ & $\delta \mathrm{D}=7.2 \delta^{18} \mathrm{O}+0.16 ; \mathrm{R}^{2}=0.96 ; n=51$ & $0.15,-12.6 ;-18.6,-90.7$ \\
Groundwater & $\delta \mathrm{D}=6.8 \delta^{18} \mathrm{O}+0.38 ; \mathrm{R}^{2}=0.97 ;$ & $-6.06,-10.9 ;-42.7,-74.5$ \\
$\begin{array}{l}\text { (Deep } 30 \mathrm{~m}) \\
\text { Groundwater }\end{array}$ & $\delta \mathrm{D}=6.2 \delta^{18} \mathrm{O}-4.2 ; \mathrm{R}^{2}=0.90 ; n=142$ & $-5.09,-10.1 ;-31.9,-67.6$ \\
$\begin{array}{l}\text { (Intermediate 10-20 m) } \\
\text { Groundwater }\end{array}$ & $\delta \mathrm{D}=6.1 \delta^{18} \mathrm{O}-5.0 ; \mathrm{R}^{2}=0.93 ; n=142$ & $-1.3,-10.9 ;-22.6,-71$ \\
(Shallow $\sim 10 \mathrm{~m})$ & $\delta \mathrm{D}=6.0 \delta^{18} \mathrm{O}-5.4 ; \mathrm{R}^{2}=0.95 ; n=142$ & $0.5,-9.9 ;-8.9,-66.6$ \\
\hline
\end{tabular}




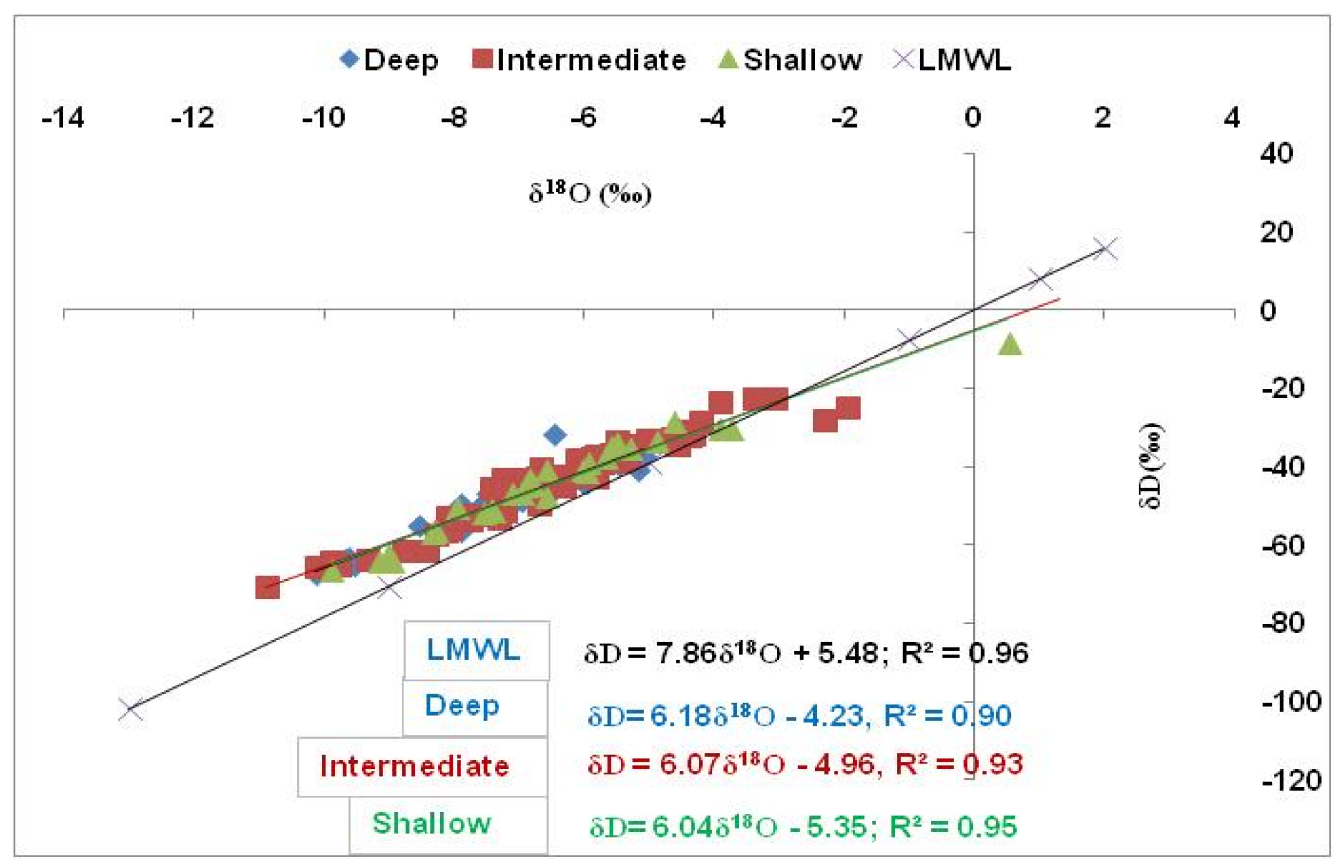

Figure 10. Cross plot $\left(\delta^{18} \mathrm{O}\right.$ and $\left.\delta \mathrm{D}\right)$ of groundwater samples in the study area.

\subsubsection{Spatial Distribution of Isotope Values of Groundwater}

To investigate the source of water recharging the groundwater, spatial distribution patterns of groundwater samples collected from four depths, viz. PZ1 ( $30 \mathrm{~m})$, PZ2 $(\sim 20 \mathrm{~m})$, PZ3 $(\sim 10 \mathrm{~m})$, and PZ4 $(5 \mathrm{~m})$, were analyzed and interpreted. Assuming that the groundwater is formed due to recharge from a combination of canal water and rainwater and that, in some locations, evaporation affects rainwater, the spatial distribution stable isotopic maps prepared for different depth aquifers were divided into seven sub-categories according to the type of recharge water: (i) 100\% recharge from the canal, (ii) recharge from canal and rain in a 60:40 ratio, (iii) recharge from canal and rain in a 40:60 ratio, (iv) 100\% recharge from rain (without any substantial evaporation before recharge), (v) recharge from rainwater subjected to moderate level of evaporation, (vi) recharge of highly evaporated rainwater, and (vii) recharge of extremely highly evaporated rainwater. Maps prepared as per these seven sub-categories for four different groundwater depths (PZ1 to PZ4) are shown in Figure 11.

The recharging areal extent of recharge contributed by different recharge sources (as classified into seven sub-categories) to a depth of up to $30 \mathrm{~m}$ is estimated using GIS tools (Table 2). Source-wise, the contribution of different recharging sources in recharging the groundwater (up to an aquifer depth of $30 \mathrm{~m}$ ) comes out to be in the decreasing order of rain $(\sim 49.7 \%)>$ rain + canal in a $60: 40$ ratio $(\sim 21.6 \%)>$ moderately evaporated rainwater $(12.7 \%)>$ canal $(7 \%)>$ highly evaporated rainwater $(5 \%)>$ canal + rain in a $60: 40$ ratio $(2.7 \%)$. Overall, $82.7 \%$ of groundwater is formed from rain and the remaining $17.3 \%$ from canal water.

The isotopic comparison of the inter-aquifer groundwater system (PZ1 to PZ4) indicates both common and dissimilar features depending on the region of observation. The entire eastern part of the deep groundwater (PZ1) shows the canal as the major recharge source, but the immediate overlying aquifer (PZ2) does not show this feature. A large area falling in the southwest zone of the shallow aquifer (PZ4) shows groundwater of canal origin, but the immediate underlying aquifer (PZ3) shows its groundwater as being formed from partially evaporated rainwater. Groundwater in PZ3 shows a much larger portion of partially evaporated rainwater as its source of origin compared to the other overlying and underlying aquifers. 


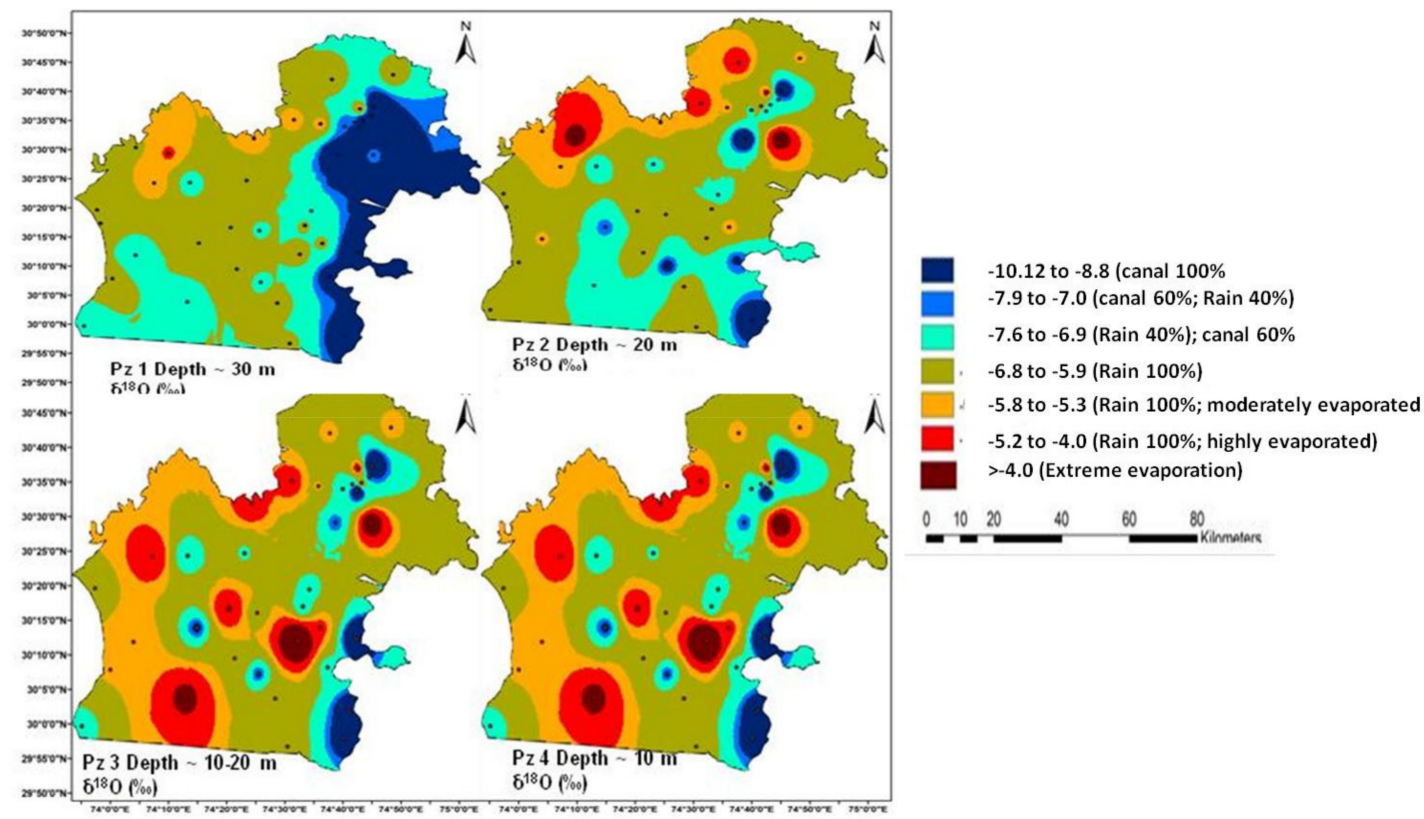

Figure 11. Spatial distribution of $\delta^{18} \mathrm{O}$ values of groundwater samples in the study area.

Table 2. Depth-wise recharge source area covered in the study area.

\begin{tabular}{|c|c|c|c|c|c|}
\hline \multirow{2}{*}{$\begin{array}{l}\text { Groundwater Recharge Source } \\
\text { (Code: Canal (C); Rain (R)) }\end{array}$} & \multirow[b]{2}{*}{ Isotopic Range (\%o) } & \multicolumn{4}{|c|}{ Aquifer Area Covered (\%) at Different Depths } \\
\hline & & $\begin{array}{c}\mathrm{PZ4} \\
(<5 \mathrm{~m})\end{array}$ & $\begin{array}{c}\text { PZ3 } \\
(\sim 10 \mathrm{~m})\end{array}$ & $\begin{array}{c}\mathrm{PZ2} \\
(\sim 20 \mathrm{~m})\end{array}$ & $\begin{array}{c}\text { PZ1 } \\
(\sim 30 \mathrm{~m})\end{array}$ \\
\hline C $(100 \%)$ & -10.12 to -8.8 & 18.96 & 2.33 & 3.13 & 3.68 \\
\hline$C(60 \%)+$ Rain $(40 \%)$ & -7.9 to -7.0 & 4.83 & 1.78 & 1.59 & 2.68 \\
\hline $\mathrm{R}(60 \%)+\mathrm{C}(40 \%)$ & -6.6 to -6.9 & 26.47 & 21.82 & 11.18 & 27.11 \\
\hline$R(100 \%)$ & -6.8 to -5.9 & 43.01 & 55.23 & 49.31 & 51.41 \\
\hline Moderately evaporated rain water & -5.8 to -5.3 & 6.56 & 12.88 & 22.02 & 9.24 \\
\hline Highly evaporated rain water & -5.2 to -4.0 & 0.17 & 5.13 & 10.59 & 4.47 \\
\hline Extremely highly evaporated rain water & $>-4.0$ & 0.00 & 0.84 & 2.17 & 1.41 \\
\hline
\end{tabular}

These dissimilarities indicate the origin of groundwater of these aquifers from the particular region lying outside the study area. Some common features that can be seen between these aquifers are that groundwater in the southeastern zone shows the canal as the source of recharge at all depths, and groundwater in the northern zone shows evaporated rainwater as the source of recharge in aquifers at all depths. These characteristics indicate vertical transmittance of groundwater from shallow to deep aquifers due to their unconfined conditions.

\subsubsection{Isotope Data Interpretation for Aquifer Interaction Studies}

In order to examine the interaction between the aquifers, the isotopic composition of groundwater between the underlying and overlying aquifers is inter-compared at the piezometric depths PZ1, PZ2, PZ3 and PZ4. The inter-comparison was done along four NE-SW-trending cross-sectional lines (AB, CD, EF, and GH). These lines are taken in the direction parallel to the topographic slope. Similarly, isotopic inter-comparison was done along four $\mathrm{N}-\mathrm{S}$ trending cross-sectional lines $\left(\mathrm{A}^{\prime} \mathrm{B}^{\prime}, \mathrm{C}^{\prime} \mathrm{D}^{\prime}, \mathrm{E}^{\prime} \mathrm{F}^{\prime}\right.$, and $\left.\mathrm{G}^{\prime} \mathrm{H}^{\prime}\right)$. All these lines were drawn carefully to see that they connect the maximum number of observation locations to make the data evaluation more closely resemble the observed data, as well as to minimize the interpolated region. The NE-SW- and N-S-trending lines at four depths are shown in Figures 12 and 13. Each of these lines was then sub-divided into approximately 30 cells of size $\sim 2.5 \mathrm{~km} \times 2.5 \mathrm{~km}$, and the isotopic values of these cells were read. Isotopic 
values of groundwater along these eight lines $\left(\mathrm{AB}, \mathrm{CD}, \mathrm{EF}, \mathrm{GH}, \mathrm{A}^{\prime} \mathrm{B}^{\prime}, \mathrm{C}^{\prime} \mathrm{D}^{\prime}, \mathrm{E}^{\prime} \mathrm{F}^{\prime}\right.$, and $\left.\mathrm{G}^{\prime} \mathrm{H}^{\prime}\right)$ at the four piezometric depths (PZ1, PZ2, PZ3, and PZ4) were then inter-compared. The observed inter-comparison is shown in Figures 14-16. The inter-comparison is interpreted based on the following parameters:

1. On the basis of isotopic composition of groundwater, the source of recharge to the groundwater is designated as (i) canal (100\%), (ii) canal $(60 \%)+$ rain (40\%), (iii) canal $(40 \%)+$ rain $(60 \%)$, (iv) rain $(100 \%)$, (v) moderately evaporated rain, (vi) highly evaporated rain water, and (vii) extremely evaporated rain water.

2. A similar isotopic composition of groundwater in the overlying and underlying aquifers indicates the recharge of the underlying aquifer from the overlying aquifer, indicating a semi-confined condition between them (in Figures 14-16, the recharge from the overlying aquifer is shown by arrow marks).

3. Non-similarity in the isotopic composition of groundwater in the overlying and underlying aquifers indicates that the recharging sources of the overlying and underlying aquifers are different (indicating a confined condition of the underlying aquifer). In Figures 14-16, non-interconnectivity is shown by the "?" mark. This means that the underlying aquifer is getting recharged from areas lying outside the study area.

4. The aquifers are considered to be marginally interactive if the commonality in isotopic signatures of the overlying and underlying aquifers is not more than $20 \%$ of the cross-sectional length.

5. Interaction between the overlying and underlying aquifers is considered to be good if, isotopically, groundwater between these aquifers shows common signatures over $20 \%$ to $40 \%$ of the cross-sectional length.

6. The underlying aquifer is considered to be recharging largely from the overlying aquifer if the isotopic signatures of the overlying and underlying aquifers are similar over more than $40 \%$ of the cross-section length.

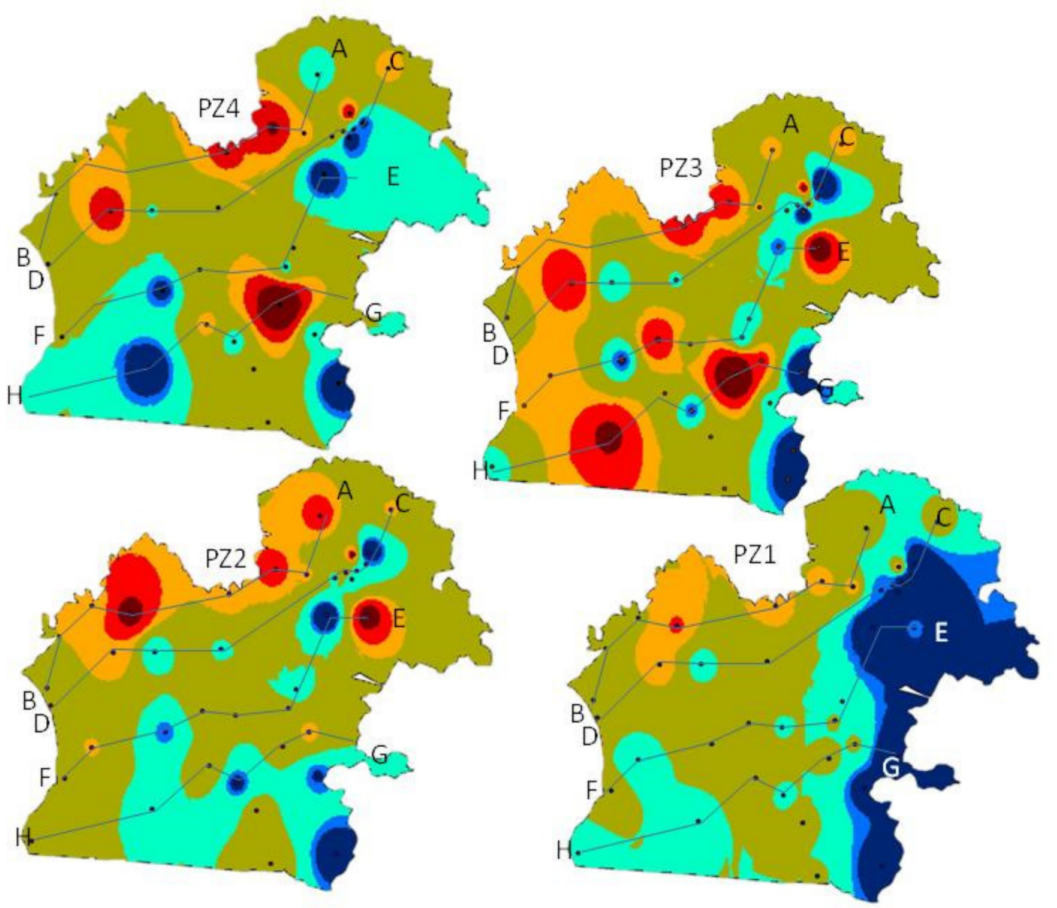

Figure 12. Spatial distribution of $\delta^{18} \mathrm{O}$ values of groundwater samples in study area. Lateral cross sections, A-B, C-D, E-F, and G-H for mapping the inter-aquifer interaction. 

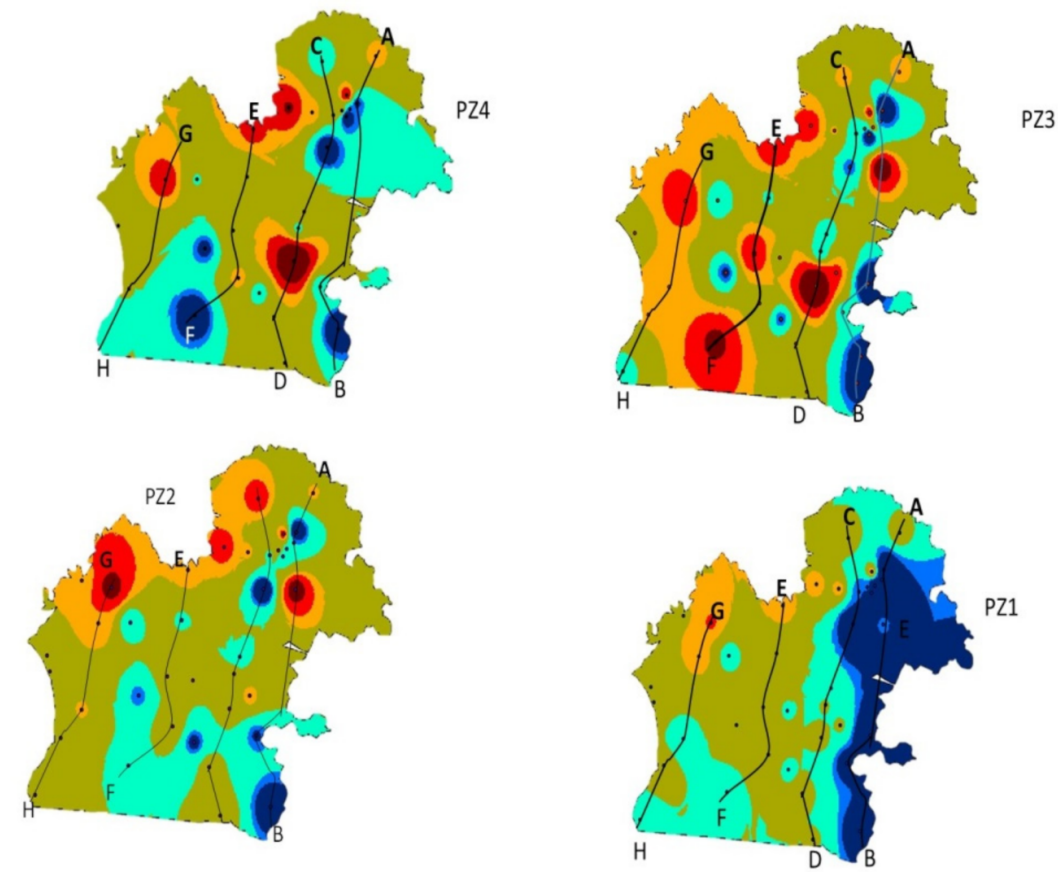

Figure 13. Vertical cross sections, A-B, C-D, E-F, and G-H for mapping the inter-aquifer interaction.

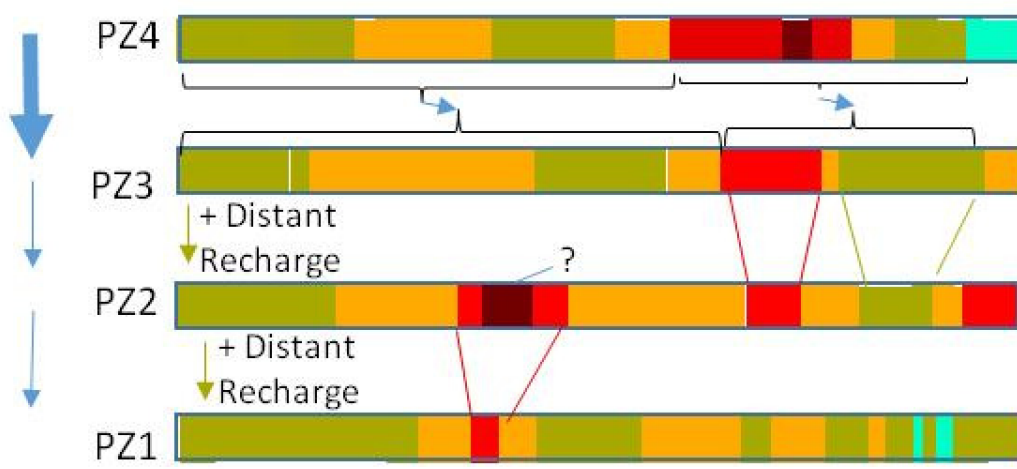

A-B

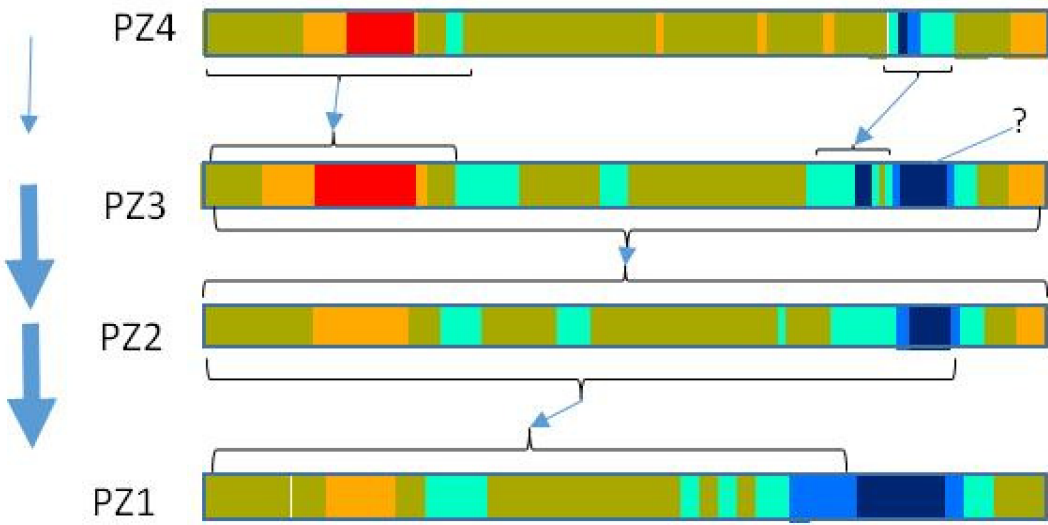

1 Marginal inter-connection: (interaction in less than 20\% area)

$\checkmark$ Good inter-connection (interaction in more than $20-40 \%$ of the area)

1 Very high inter-connection (interaction in more than $40 \%$ of the area)

Figure 14. Interactions in $\mathrm{A}-\mathrm{B}$ and $\mathrm{C}-\mathrm{D}$ cross-sections. 

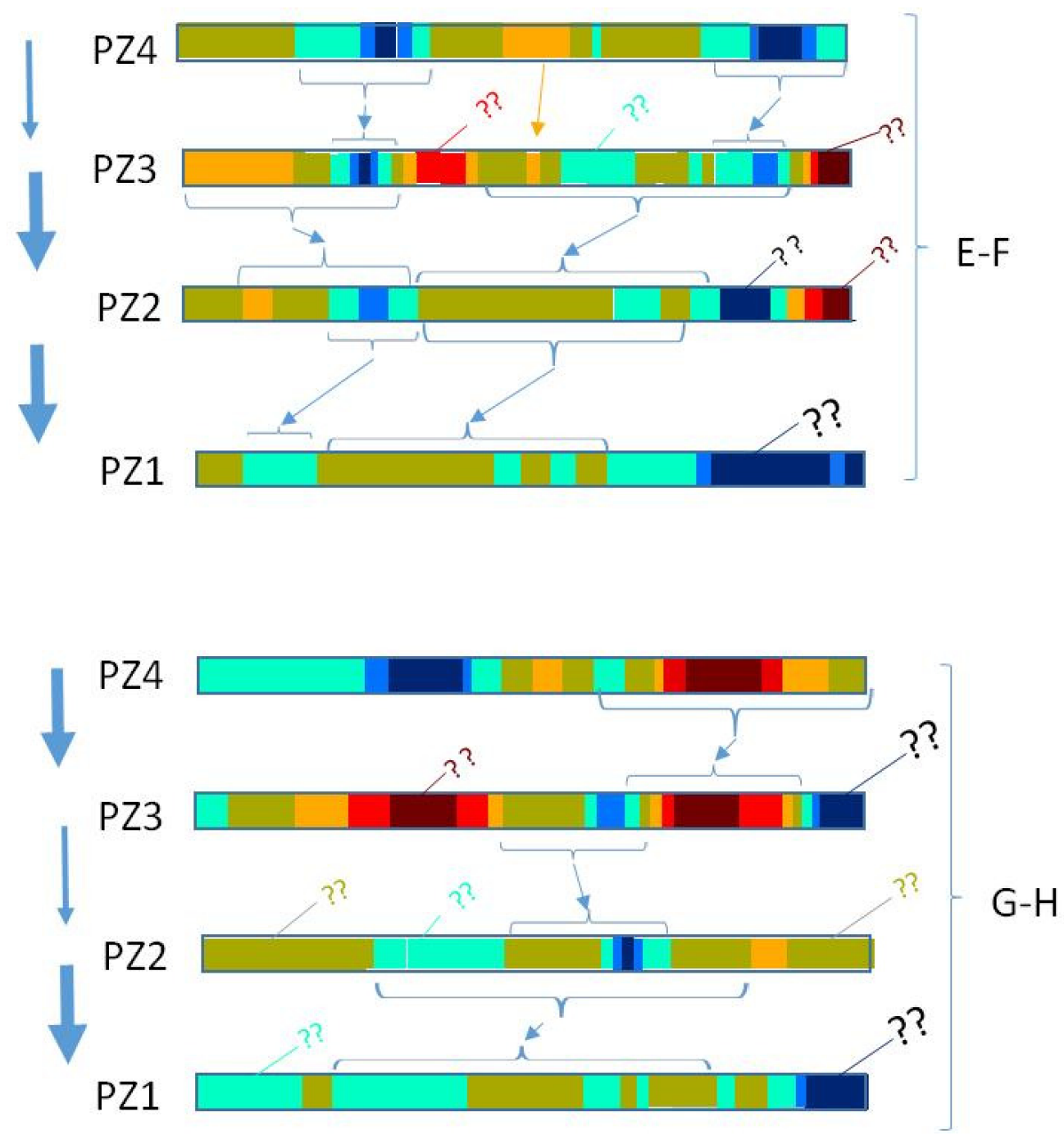

Figure 15. Interactions in $\mathrm{E}-\mathrm{F}$ and $\mathrm{G}-\mathrm{H}$ cross-sections. Brackets and line enclosed zone indicates aquifer interaction region; ? (unknown) indicates zone of recharge area lying outside the study area. $R, C, R+C, R H E$, RME indicate the recharge sources as rain, canal, rain + canal, rain-highly evaporated water, and rain-moderately evaporated water, respectively, as well as the extent of evaporation prior to the recharge process.

Using the above six points, the recharge sources (rain, canal water, and their combination) and the level of interaction between the overlying and underlying aquifers is interpreted and is presented in Figures 14-16 and Table 3.

On the basis of color codes (similar isotopic value), correlation between the overlying and underlying aquifers is examined. A positive correlation indicates an interaction between the two aquifers (due to leakage or water exchange during irrigation activities). In the case that the underlying aquifer has different color code (isotopic value), then this indicates no recharge from the overlying aquifer. On this basis, the extent of interaction along all 32 cross sections was examined.

Regions with common isotopic signatures were considered a zone of interaction between the overlying and the underlying aquifers. Based on the extent of interaction, the aquifers along the cross-sections were demarcated as: (i) marginal inter-connection zones (interaction in less than $20 \%$ of the area), (ii) good inter-connection zones (interaction in more than $20-40 \%$ of the area), and (iii) very high inter-connection zones (interaction in more than $40 \%$ of the area). 

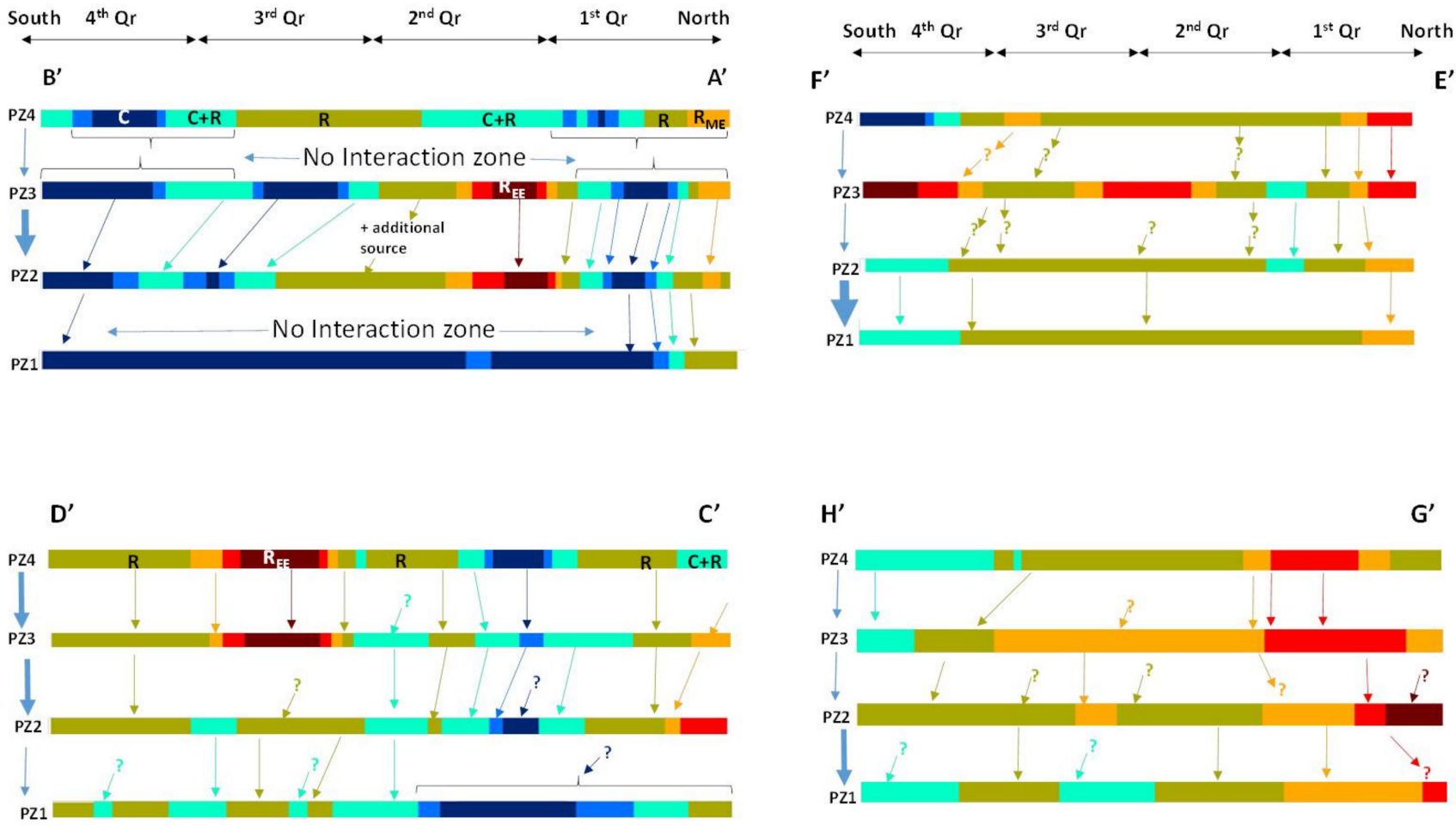

Figure 16. Water type and inter-aquifer interactions along the vertical cross-sections $A^{\prime}-B^{\prime}, C^{\prime}-D^{\prime}$, $E^{\prime}-F^{\prime}$, and $G^{\prime}-H$.

Table 3. Groundwater flow between the aquifers (inter-aquifer interaction) along the cross-sections A-B, C-D, E-F and G-H.

\begin{tabular}{cccccc}
\hline \multirow{2}{*}{$\begin{array}{c}\text { Cross } \\
\text { Section }\end{array}$} & Aquifer & \multicolumn{2}{c}{ Level of Inter-Connectivity in the Segment Zones 1 to 4 } \\
\cline { 3 - 6 } & & $\mathbf{1}$ & $\mathbf{2}$ & $\mathbf{3}$ & $\mathbf{4}$ \\
\hline \multirow{3}{*}{ A-B } & PZ4 to PZ3 & Moderate & Nil & Nil & Moderate \\
& PZ3 to PZ2 & Very Good & Moderate & Low & Moderate \\
& PZ2 to PZ1 & Low & Nil & Nil & Very low \\
\hline \multirow{2}{*}{ C-D } & PZ4 to PZ3 & Low & Moderate & Good & Very good \\
& PZ3 to PZ2 & Moderate & Good & Nil & Very good \\
& PZ2 to PZ1 & Nil & Low & Low & Moderate \\
\hline \multirow{2}{*}{ E-F } & PZ4 to PZ3 & Good & Nil & Nil & Nil \\
& PZ3 to PZ2 & Moderate & Very low & Very low & Very low \\
& PZ2 to PZ1 & Moderate & Very good & Very good & Very good \\
\hline \multirow{2}{*}{ G-H } & PZ4 to PZ3 & Moderate & Very low & Nil & Moderate \\
& PZ3 to PZ2 & Very low & Very low & Moderate & Moderate \\
& PZ2 to PZ1 & Moderate & Good & Low & Very low
\end{tabular}

The extent of interaction is divided into 5 groups as (i) very low, (ii) low, (iii) moderate, (iv) good, and (v) very good. For convenience, the cross-section length is divided into 4 segments (1-4), as shown in Figure 16.

Salinity in groundwater arises from the combination of evaporation enrichment and salt dissolution. The dissolved salts may be acquired from the salts of aquifer materials or the salts of surface soils that have dissolved and leached down with the recharging water. The process of salinity in groundwater may be checked by correlating the EC and stable isotopic maps. The zone of interaction between the aquifers can be effectively used in groundwater augmentation, management, and contamination control. The zone of interaction in the present study is mapped using stable isotopic composition.

In Figure 16, the color band represents the isotopic range (indicating the source water type) of the groundwater at that location and depth. Arrows between the aquifers indicate possible interconnectivity between the aquifers (due to similarity in their isotopic 
composition). The "?" indicates that the source water is not arising from the overlying aquifer, but rather as inflow from an area falling outside the cross-section zone. The resolution of the color band (minimum width in $\mathrm{km}$ that corresponds to a color line in the color band) is $\sim 1 \mathrm{~km}$.

For Figures 14-16, an explanation of the symbols and text is given in Figure 17:

\section{Marginal Interaction: \\ (Interaction in less \\ than $20 \%$ of the cross \\ section length)}

\section{Good interconnection \\ (Interaction in more \\ than $20-40 \%$ of the \\ cross section lengh)}

\section{Very high \\ interconnection \\ (Interaction in more \\ than $40 \%$ of the cross \\ section length)}

- Brackets and line enclosed zone indicates aquifer interaction region

- ? Indicates zone of recharge area lying outside the study area

- $R, C, R+C, R H E, R M E$ indicate the recharge sources and the extent of evaporation prior to the recharge process

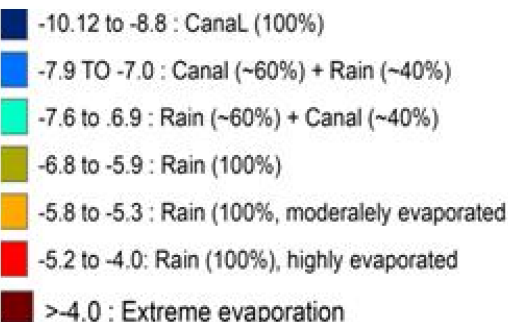

Figure 17. Explanation of the symbols and text in Figures 14-16.

The temporal variation of groundwater levels monitored in three districts in 2000 and 2014 showed that the groundwater level varies between 0.20 and $27.40 \mathrm{~m}-\mathrm{bgl}$ (168.45 to $220.45 \mathrm{~m}$ asl). It has been found that groundwater samples from about $31 \%$ of piezometers are marginally saline to saline $(>2450 \mu \mathrm{S} / \mathrm{cm})$. The isotopic comparison of the interaquifer groundwater system (PZ1 to PZ4) indicates both common and dissimilar features depending on the region of observation. These features are discussed as follows: The entire eastern part of the deep groundwater (PZ1) shows the canal as the major recharge source. However, the immediate overlying aquifer (PZ2) does not show this feature. A large area falling in the southwest zone of the shallow aquifer (PZ3) shows groundwater of canal origin, but the immediate underlying aquifer (PZ4) shows its groundwater as being formed from partially evaporated rainwater. Groundwater in PZ3 shows a much larger extent of evaporated rainwater as its source of origin compared to the other overlying and underlying aquifers.

The characteristics indicate vertical transmittance of groundwater from shallow to deep aquifers due to two unconfined conditions [39]. Firstly, groundwater in the southeastern zone shows the canal as the source of recharge at all depths. Secondly, groundwater in the northern zone shows evaporated rainwater in aquifers at all depths. Interactions between aquifers were assessed based on the isotope values, and it was found that regions with common isotopic signatures were considered zones of interaction between the overlying and the underlying aquifers $[40,41]$. Based on the extent of the interaction, the aquifers along the cross-sections were demarcated into three categories: (i) marginal inter-connection zones (interaction in less than $20 \%$ area), (ii) good inter-connection zones (interaction in more than $20-40 \%$ of the area), and (iii) very high inter-connection zones (interaction in more than $40 \%$ of the area). 


\section{Conclusions}

On the basis of long-term groundwater fluctuations, areas are identified where groundwater may enter into the high-risk (dark) zone in the next 20 years, which needs urgent attention. From this study, the following suggestive measures can be provided for these areas: (i) where groundwater is getting recharged (or in identified recharge zones) on the basis of isotope analysis, these zones should be preferred for artificial recharge measures, and (ii) where canals are significant contributors to the groundwater, there is a need to maintain clean canal water so that interaction helps increase fresh groundwater resources. Low-water-intensive crops should be suggested in such areas.

There is a need to identify the sites where groundwater is picking up additional salinity when it is passing through. There is also an immediate need to install observation stations to monitor groundwater quality and levels at vulnerable locations, especially in fringe areas, where on one side groundwater quality is good, and immediately on the other side it deteriorates; areas where groundwater levels are becoming shallow and waterlogging may therefore occur; and areas where groundwater is deepening that may become dark zones. However, the conclusion drawn needs to be substantiated by groundwater age dating or any other suitable technique before field implementation. There is a need for detailed study to find out the sources of salinity and possible remedial measures.

Author Contributions: G.K.: Conceptualization, writing manuscript draft, supervision; M.S.R.: Isotope analysis and interpretation; R.V.: Conceptualization; A.C.: Preparing maps; J.S.: Experimentation and piezometer construction; A.K.: Review and editing and funding acquisition. All authors have read and agreed to the published version of the manuscript.

Funding: Funding for research received from the Department of Agriculture and Farmers' Welfare, Punjab under the Crop Diversification Project is duly acknowledged. The article processing charge (APC) was funded by National Science Foundation of China (NSFC)-International young scientist Project (Grant no: 52150410400).

Institutional Review Board Statement: Not needed or available.

Informed Consent Statement: Not available or needed for this study.

Data Availability Statement: Data used in this study are duly available from the first authors on reasonable request.

Acknowledgments: The authors are thankful to the NIH and the head of the Groundwater Hydrology division for all their support and encouragement. Thanks to the staff of the Nuclear Hydrology Lab for stable isotope analysis. Thanks to Ankur for assisting with analysis and sample collection.

Conflicts of Interest: The authors declare no conflict of interest.

\section{References}

1. Bonsor, H.C.; MacDonald, A.M.; Ahmed, K.M.; Burgess, W.G.; Basharat, M.; Calow, R.C.; Dixit, A.; Foster, S.S.D.; Gopal, K.; Lapworth, D.J.; et al. Hydrogeological typologies of the Indo-Gangetic basin alluvial aquifer, South Asia. Hydrogeol. J. 2017, 25, 1377-1406. [CrossRef]

2. Rodell, M.; Velicogna, I.; Famiglietti, J.S. Satellite-based estimates of groundwater depletion in India. Nature 2009, 460, 999-1002 [CrossRef] [PubMed]

3. NASA. Study: Third of Big Groundwater Basins in Distress. 2015. Available online: https://www.nasa.gov/jpl/grace/studythird-of-big-groundwater-basins-in-distress (accessed on 27 December 2020).

4. MacDonald, A.M.; Bonsor, H.C.; Ahmed, K.M.; Burgess, W.G.; Basharat, M.; Calow, R.C.; Dixit, A.; Foster, S.S.; Gopal, K.; Lapworth, D.J.; et al. Groundwater depletion and quality in the Indo-Gangetic basin mapped from in situ observations. Nat. Geosci. 2016, 9, 762-766. [CrossRef]

5. Custodio, E. Coastal aquifer salinization as a consequence of aridity: The case of Amurga phonolitic massif, Gran Canaria Island, in Study and Modelling of Saltwater Intrusion. In Proceedings of the 12th Saltwater Intrusion Meeting, Barcelona, Spain, First Week of November 1992; pp. 81-98.

6. Krishan, G.; Ghosh, N.C.; Kumar, C.P.; Sharma, M.; Yadav, L.; Kansal, M.L.; Singh, S.; Verma, S.K.; Prasad, G. Understanding stable isotope systematics of salinity affected groundwater in Mewat, Haryana, India. J. Earth Syst. Sci. 2020, 129, 109. [CrossRef]

7. Gopinath, S.; Srinivasamoorthy, K.; Saravanan, K.; Prakash, R. Tracing groundwater salinization using geochemical and isotopic signature in Southeastern coastal Tamilnadu, India. Chemosphere 2019, 236, 124305. [CrossRef] 
8. Bennetts, D.A.; Webb, J.A.; Stone, D.J.M.; Hill, D.M. Understanding the salinisation process for groundwater in an area of south-eastern Australia, using hydrochemical and isotopic evidence. J. Hydrol. 2006, 323, 178-192. [CrossRef]

9. Jouzel, J.; Delaygue, G.; Landais, A.; Masson-Delmotte, V.; Risi, C.; Vimeux, F. Water isotopes as tools to document oceanic sources of precipitation. Water Resour. Res. 2013, 49, 7469-7486. [CrossRef]

10. Argamasilla, M.; Barber'a, J.A.; Andreo, B. Factors controlling groundwater salinization and hydrogeochemical processes in coastal aquifers from southern Spain. Sci. Total Environ. 2017, 580, 50-68. [CrossRef]

11. Krishan, G.; Prasad, G.; Kumar, C.P.; Patidar, N.; Yadav, B.K.; Kansal, M.L.; Singh, S.; Sharma, L.M.; Bradley, A.; Verma, S.K. Identifying the seasonal variability in source of groundwater salinization using deuterium excess-A case study from Mewat, Haryana, India. J. Hydrol. Reg. Stud. 2020, 31, 100724. [CrossRef]

12. Appelo, C.; Postma, D. Geochemistry, Groundwater and Pollution, 2nd ed.; Balkema: Rotterdam, The Netherlands, 2005. [CrossRef]

13. Adimalla, N. Groundwater Quality for Drinking and Irrigation Purposes and Potential Health Risks Assessment: A Case Study from Semi-Arid Region of South India. Expo. Health 2019, 11, 109-123. [CrossRef]

14. Singh, S.; Kumar, A.; Gupta, H. Activated banana peel carbon: A potential adsorbent for Rhodamine B decontamination from aqueous system. Appl. Water Sci. 2020, 10, 185. [CrossRef]

15. Kumar, A.; Jigyasu, D.K.; Subrahmanyam, G.; Mondal, R.; Shabnam, A.A.; Cabral-Pinto, M.M.S.; Malyan, S.K.; Chaturvedi, A.K.; Gupta, D.K.; Fagodiya, R.K.; et al. Nickel in terrestrial biota: Comprehensive review on contamination, toxicity, tolerance and its remediation approaches. Chemosphere 2021, 275, 129996. [CrossRef]

16. Kumar, A.; Pinto, M.C.; Candeias, C.; Dinis, P.A. Baseline maps of potentially toxic elements on soils of Garhwal Himalaya, India: Assessment of their eco-environmental and human health risks. Land Degrad. Dev. 2021, 32, 3856-3869. [CrossRef]

17. Houéménou, H.; Tweed, S.; Dobigny, G.; Mama, D.; Alassane, A.; Silmer, R.; Babic, M.; Ruy, S.; Chaigneau, A.; Gauthier, P.; et al Degradation of groundwater quality in expanding cities in West Africa. A case study of the unregulated shallow aquifer in Cotonou. J. Hydrol. 2020, 582, 124438. [CrossRef]

18. Modibo Sidibé, A.; Lin, X.; Koné, S. Assessing Groundwater Mineralization Process, Quality, and Isotopic Recharge Origin in the Sahel Region in Africa. Water 2019, 11, 789. [CrossRef]

19. Krishan, G.; Sudersan, N.; Sidhu, B.S.; Vashisth, R. Impact of lockdown due to COVID 19 pandemic on Groundwater salinity in Punjab, India: Some hydrogeoethics issues. Sustain. Groundw. Resour. Manag. 2021, 7, 27. [CrossRef] [PubMed]

20. Krishan, G.; Taloor, A.K.; Sudarsan, N.; Bhattacharya, P.; Kumar, S.; Ghosh, N.C.; Singh, S.; Sharma, A.; Rao, M.S.; Mittal, S.; et al Occurrences of potentially toxic trace metals in groundwater of the state of Punjab in northern India. Groundw. Sustain. Dev. 2021, 15, 100655. [CrossRef]

21. Krishan, G.; Kumar, B.; Sudarsan, N.; Rao, M.S.; Ghosh, N.C.; Taloor, A.K.; Bhattacharya, P.; Singh, S.; Kumar, C.P.; Sharma, A.; et al. Isotopes $\left(\delta^{18} \mathrm{O}, \delta \mathrm{D}\right.$ and $\left.{ }^{3} \mathrm{H}\right)$ variations in groundwater with emphasis on salinization in the State of Punjab, India. Sci. Total Environ. 2021, 789, 148051. [CrossRef]

22. Krishan, G.; Vashisth, R.; Sudersan, N.; Rao, M.S. Groundwater salinity and isotope characterization: A case study from south-west Punjab, India. Environ. Earth Sci. 2021, 80, 169. [CrossRef]

23. Yehdeghoa, B.; Rozanski, K.; Zojer, H.; Stichler, W. Interaction of dredging lakes with the adjacent groundwater field: An isotope study. J. Hydrol. 1997, 192, 247-270. [CrossRef]

24. Wang, W.; Yi, Y.; Zhong, J.; Kumar, A.; Li, S.L. Carbon biogeochemical processes in a subtropical karst river-reservoir system. J. Hydrol. 2020, 591, 125590. [CrossRef]

25. Bhat, M.A.; Zhong, J.; Dar, T.; Kumar, A.; Li, S.L. Spatial distribution of stable isotopes in surface water on the upper Indus River basin (UIRB): Implications for moisture source and paleoelevation reconstruction. Appl. Geochem. 2022, 136, 105137. [CrossRef]

26. Kumar, R.; Rani, M.; Gupta, H.; Gupta, B.; Park, D.; Jeon, B.H. Distribution of trace elements in flowing surface waters: Effect of seasons and anthropogenic practices in India. Int. J. Environ. Anal. Chem. 2017, 97, 637-656. [CrossRef]

27. Dansgaard, W. Stable isotopes in precipitation. Tellus 1994, 16, 436-468.

28. Zhu, L.; Fan, M.; Hough, B.; Li, L. Spatiotemporal distribution of river water stable isotope compositions and variability of lapse rate in the central Rocky Mountains: Controlling factors and implications for paleoelevation reconstruction. Earth Planet. Sci. Lett. 2018, 496, 215-226. [CrossRef]

29. Nayak, P.C.; Kumar, S.V.; Rao, P.R.; Vijay, T. Recharge source identification using isotope analysis and groundwater flow modeling for Puri city in India. Appl. Water Sci. 2017, 7, 3583-3598. [CrossRef]

30. Ahmed, I.M.; Jalludin, M.; Razack, M. Hydrochemical and Isotopic Assessment of Groundwater in the Goda Mountains Range System. Republic of Dibouti (Horn of Africa). Water 2020, 12, 2004. [CrossRef]

31. CENSUS. 2011. Available online: http:/ / www.census2011.co.in/census/district/226-mewat.html (accessed on 13 January 2021)

32. CGWB. Aquifer Mapping and Management Plan, North Western Region. Central Groundwater Board, Ministry of Water Resources; Government of India: Chandigarh, India, 2017.

33. CGWB, Goverment of India. Groundwater Resources of Punjab State-As on 31st March, 2017-Prepared by CGWB-NWR and Water Resources and Environment Directorate; Government of Punjab: Punjab, India, 2018; p. 176.

34. APHA. Standard Methods for the Examination of Water and Waste Water, 22nd ed.; American Public Health Association: Washington, DC, USA; American Water Works Association: Denver, CO, USA; Water Environment Federation: Virginia, VA, USA, 2012.

35. Kumar, A.; Taxak, A.K.; Mishra, S.; Pandey, R. Long term trend analysis and suitability of water quality of River Ganga at Himalayan hills of Uttarakhand, India. Environ. Technol. Innov. 2021, 22, 101405. [CrossRef] 
36. Van Weert, F.; Van der Gun, J.; Reckman, J. Global Overview of Saline Groundwater Occurrence and Genesis; IGRAC: Utrecht, The Netherlands, 2009.

37. IS: 10500; Specifications for Drinking Water. Bureau of Indian Standards: New Delhi, India, 2012.

38. Krishan, G.; Rao, M.S. Isotope Hydrology; Lambert Publishing House: Saarbrücken, Germany, 2013; p. 513.

39. Lapworth, D.J.; Krishan, G.; MacDonald, A.M.; Rao, M.S. Groundwater quality in the alluvial aquifer system of northwest India: New evidence of the extent of anthropogenic and geogenic contamination. Sci. Total Environ. 2017, 599, 1433-1444. [CrossRef]

40. Carol, E.; Kruse, E.; Mas-Pla, J. Hydrochemical and isotopical evidence of ground water salinization processes on the coastal plain of Samborombón Bay, Argentina. J. Hydrol. 2009, 365, 335-345. [CrossRef]

41. Gibbs, R.J. Mechanisms controlling world water chemistry. Science 1970, 170, 1088-1090. [CrossRef] [PubMed] 